\title{
Distamycin Analogues without Leading Amide at Their $N$-Termini - Comparative Binding Properties to AT- and GC-Rich DNA Sequences
}

\author{
Mini Thomas, ${ }^{[a, b]}$ Umesh Varshney, ${ }^{[b]}$ and Santanu Bhattacharya*[a]
}

Keywords: AT and GC recognition / Distamycin analogues / DNA recognition / Drug research / Synthesis

An efficient, simple and general route towards the solutionphase synthesis of four distamycin analogues containing 2-5 $N$-methylcarboxamide units without the leading amide unit at the $N$-terminus is described. The binding abilities of these molecules to calf thymus DNA, poly d(AT), poly dA.poly dT and poly $\mathrm{d}(\mathrm{GC})$ were evaluated by duplex DNA melting temperature $\left(T_{m}\right)$ analysis, fluorescence probe displacement assay, footprinting studies and induced circular dichroism (ICD) measurements. A minimum of three $N$-methylpyrrolecarboxamide units was found to be necessary for the onset of DNA binding. The other three analogues exhibited AT-specific footprints on DNA at a salt concentration of $40 \mathrm{mM} \mathrm{NaCl}$. Interestingly, intense ICD spectra were obtained not only with AT-rich DNA tracts, but also with poly $d(G C)$. Though these
ICD signals were sensitive to changes in salt concentration of the solution, residual ICD was present even at $[\mathrm{NaCl}]$ values as high as $4.8 \mathrm{M}$, at which poly d(GC) is likely to exist in the $\mathrm{Z}$ conformation. This implies that nonelectrostatic interactions are involved in the binding process involving poly $\mathrm{d}(\mathrm{GC})$ and also that binding is preserved even with the $\mathrm{Z}$ form of DNA. These results have significance on account of the growing interest in polyamide-based minor groove binders as artificial gene regulators and also in view of the increasing evidence for the biological significance of the $\mathrm{Z}$ morph of DNA.

(c) Wiley-VCH Verlag GmbH, 69451 Weinheim, Germany, 2002)

\section{Introduction}

Designing of molecules capable of recognizing specific sequences in DNA may be useful for achieving selective inhibition of the expression of certain oncogenes. This would also allow control over the development and proliferation of tumor cells. Chemical biologists' approach toward this goal has been to use low-molecular-weight ligands that would bind specific sequences in DNA. ${ }^{[1]}$ The natural product distamycin (Dst) remains the principal candidate for spearheading such designs. ${ }^{[1 \mathrm{a}, 1 \mathrm{~b}]}$ Dst binds to five consecutive AT base pairs, and its binding site coincides with that of the TATA-box binding protein (TBP), which is a general transcription factor for RNA polymerase II. ${ }^{[2]}$ Structural, ${ }^{[3]}$ thermodynamic ${ }^{[4]}$ and spectroscopic ${ }^{[5]}$ studies have established the molecular basis for the DNA-binding affinity and specificity of Dst, a related compound netropsin $(\mathrm{Nt})$ and other synthetic minor groove binders such as Hoechst33258. From this information, a set of pairing rules for the recognition of all four Watson-Crick DNA base pairs has also been developed. ${ }^{[1 \mathrm{a}, 1 \mathrm{~b}, 6]}$ Thus, the progress with poly-

[a] Department of Organic Chemistry Indian Institute of Science, Bangalore, India

Fax: (internat.) + 91-80/360-0683

E-mail: sb@orgchem.iisc.ernet.in

[b] Molecular Biology and Cell Biology, Indian Institute of Science Bangalore, India

Fax: (internat.) + 91-80/360-2697

E-mail: varshney@mcbl.iisc.ernet.in amide-based minor groove binders forms an excellent example of molecular recognition by design. Many such designs have been found to exhibit useful biological activities. ${ }^{[1,7]}$

In addition to the regular B-form DNA, DNA-RNA chimers such as Okasaki fragments, ${ }^{[8 a]}$ G-quadruplexes ${ }^{[8 b]}$ etc. have also recently been targeted with Dst or analogues. A high level of telomerase activity has been associated with cancer cells and may be essential for their immortality. Gquadruplet $\mathrm{DNA}^{[8 \mathrm{cc}]}$ inhibits telomerase activity, and compounds that can bind to this arrangement can therefore negatively interfere with telomerase activity. ${ }^{[8 \mathrm{~d}, 8 \mathrm{e}]}$

It is also important to evaluate the DNA-binding properties of 'designer' minor groove binders to the non-standard morphs of DNA such as the $\mathrm{Z}$ form, ${ }^{[9-11]}$ since this aspect would be relevant to their biological applications. It has been reported that right-handed $\mathrm{B}$ and left-handed $\mathrm{Z}$ conformations coexist in equilibrium in the plasmid DNA of E. coli. ${ }^{[12 a]}$ They have also been detected in Drosophila chromosomes $^{[12 b]}$ and in metabolically active mammalian cells. ${ }^{[12 c]}$ Moreover, sequences that can adopt the $\mathrm{Z}$ conformation are found in the enhancer regions of the SV-40 mini-chromosome ${ }^{[12 \mathrm{~d}]}$ and between two transcription units alternatively exposed during the development of Drosophila hydei. ${ }^{[12 \mathrm{e}]}$

One way to approach this problem is by systematic examination of the effects on DNA-binding properties of various structural modifications to the Dst skeleton. Indeed, there 
have recently been reports on the solid-phase synthesis of this class of molecules. ${ }^{[13]}$ However, the synthesis of these oligopeptides in solution has remained tricky. ${ }^{[14 a-14 h]}$ Variable coupling yields, long reaction times, numerous side products and reactive intermediates make the seemingly simple synthesis of such molecules cumbersome. The $N$-formylation step was, in fact, found to be one of the least satisfactory steps of the synthetic procedures developed for distamycin, with yields in the range of $10-20 \%$ in most cases. We were intrigued by the possibility of removing the $N$ terminal formamide group of Dst altogether in order to simplify the synthesis. This modification is also significant in terms of improving the stability of the resulting molecules, since the terminal formamide unit of Dst has been reported to be susceptible to cellular degradation. ${ }^{[15]}$ We also desired to achieve solubility of the synthetic intermediates and the final compounds in common organic solvents, in order to enable them to be conveniently conjugated with other bioactive templates. This is important, as it is often not easy to adapt solid-phase synthesis for conjugation into nonpeptidic systems.

Here we report details of the solution-phase synthesis ${ }^{[14 i]}$ and complete characterization of four Dst-like oligopeptides, 1-4 (D2-D5, Figure 1), that lack the leading amide unit at their $N$-termini, together with the results of their interactions both with AT- and with GC-rich sequences of DNA.

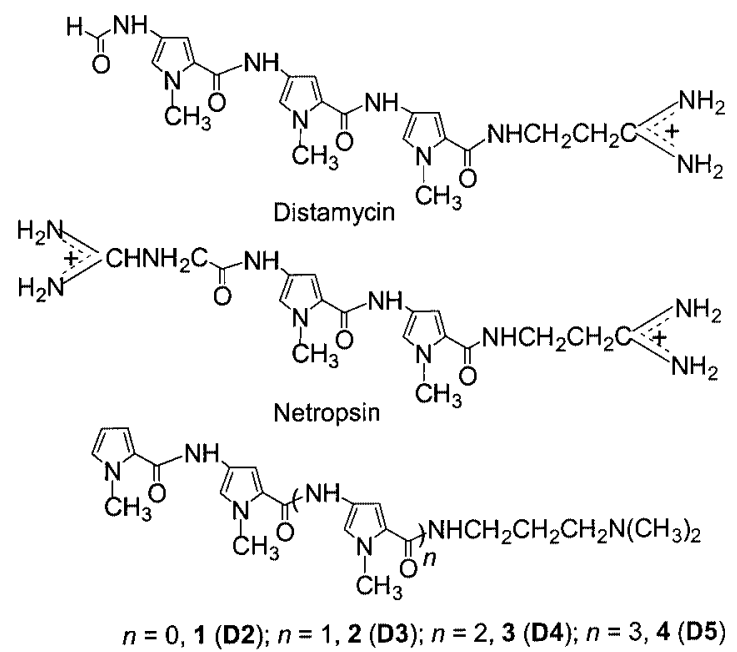

Figue 1. Chemical structures of distamycin, netropsin and the oligopeptide analogues that lack the leading amide unit

\section{Results and Discussion}

\section{Synthesis}

In most of the early approaches aimed at the synthesis of Dst, as typified by the method of Bialer et al., ${ }^{[14 \mathrm{~b}]}$ the polyamide backbone was constructed by use of acid chlorideamine coupling procedures. The $\beta$-amido propionitrile group was then introduced at the $C$-terminal, and subsequently converted into a propionamidino group under
Pinner reaction conditions. The $N$-terminus formyl group was introduced in the last step of synthesis, with the yield of this step being ca. 15\%. This procedure suffers from several disadvantages, including the use of an aqueous base for acid chloride-amine coupling reactions (which produced variable yields $)^{[14 c]}$ and the very poor yield of the formylation step. An improved method, developed by Lown et al., ${ }^{[14 \mathrm{c}]}$ employed Hunig's base in THF for the acid chloride-amine coupling reactions. The introduction of the formamido group by the use of formyl imidazole achieved a $71 \%$ yield for this step. Even though this method represented a considerable improvement over the previous methods, it required the use of 'not so common' reagents as well as sensitive reagents such as formyl imidazole. Additionally, this method could not be 'directly' applied to the synthesis of longer oligopeptide analogues of Dst. Yet another procedure, which is an exception to the general methodology discussed above, was reported by Grehn et al. ${ }^{[14 \mathrm{~d}]}$ and offered many novel features such as the use of $t$ Boc derivative of 4-amino-1-methyl-1H-pyrrole-2-carboxylic acid as the key starting material, carbodiimide-based coupling reactions and also the introduction of a preformed amino amidine side chain. However, it required as many as twelve steps for the synthesis of distamycin, and this strategy required use of exotic reagents such as tetramethyl guanidine. The efficiency of this method could not be evaluated directly since all the yields were reported on crude products.

These considerations made us look for an adaptable and general solution-phase synthetic strategy involving simple reaction conditions, common solvents and reagents that would furnish reproducible yields, while avoiding the use of column chromatography to the largest extent possible. A 'general' strategy in this context implies one that allows the synthesis of relatively long oligopeptide analogues (4-6 pyrrolecarboxamide units).

The key starting material for the synthesis, 1-methyl-4nitro- $1 H$-pyrrole-2-carboxylic acid $(\mathbf{5 c})$, was obtained in $\approx$ $40 \%$ yield by nitration of 1 -methyl- $H$-pyrrole-2-carboxylic acid (5a) by a procedure adapted, after suitable modification, from the literature. ${ }^{[14 b, 14 c]}$ These modifications helped in avoiding the use of column chromatography for the isolation of the desired 4-nitro isomer from the 3-nitro and 3,4dinitro isomers formed during the nitration step. The overall synthetic strategy for the construction of the polyamide backbone relied upon successive addition of 1-methyl-4nitro-1 $H$-pyrrole-2-carbonyl chloride (5e) to the $N$-terminus of the growing peptide chain. Thus, methyl 1-methyl-4nitro-1H-pyrrole-2-carboxylate (5d) was reduced with $\mathrm{H}_{2}-\mathrm{Pd} / \mathrm{C}$ in DMF and was coupled with 1-methyl-4-nitro$1 \mathrm{H}$-pyrrole-2-carbonyl chloride (5e) in the presence of $\mathrm{Et}_{3} \mathrm{~N}$ to obtain the nitrodipeptide $\mathbf{6 a}$ in $87 \%$ yield. Further elongation of the peptide backbone was achieved by repetition of the reduction and the amide-coupling steps. Thus the nitro derivatives 7a and 8a were obtained in 83 and $80 \%$ yields from their respective precursors. The chain growth was terminated with 1-methyl- $1 H$-pyrrole-2-carbonyl chloride $(\mathbf{5 b})$ once the desired length of the polyamide had been reached. We term the latter step "end-capping", as it pre- 
vents further extension of the amide chain from the $N$-terminus. Thus, all the nitro compounds $5 \mathbf{d}, \mathbf{6} \mathbf{b}, 7 \mathbf{a}$ and $\mathbf{8 a}$ were reduced separately and coupled with the acid chloride $\mathbf{5 b}$ to obtain the "end-capped" peptides $\mathbf{6 a}, \mathbf{7 b}, \mathbf{8 b}$ and $\mathbf{9 a}$ in 85 , 80,78 and $85 \%$ yields, respectively, from their precursors, as shown in Scheme 1 and 2. Notably, isolation of the free amine intermediates was avoided on account of their unstable nature. These were quickly separated from the reaction mixture by filtration and were immediately coupled directly with the appropriate acid chlorides. The "endcapped" methyl esters were then hydrolyzed to the corresponding acids and were subsequently converted into their activated esters with $N$-hydroxysuccinimide (HOSu) and $N, N$-dicyclohexylcarbodiimide (DCC) (Scheme 2). The $\mathrm{HOSu}$ esters were aminolyzed with $N, N$-dimethyl-1,3-diaminopropane in $\mathrm{CHCl}_{3}$ to obtain the final compounds $\mathbf{1 - 4}$ (D2-D5) in 80, 88, 90 and $82 \%$ yields, respectively.

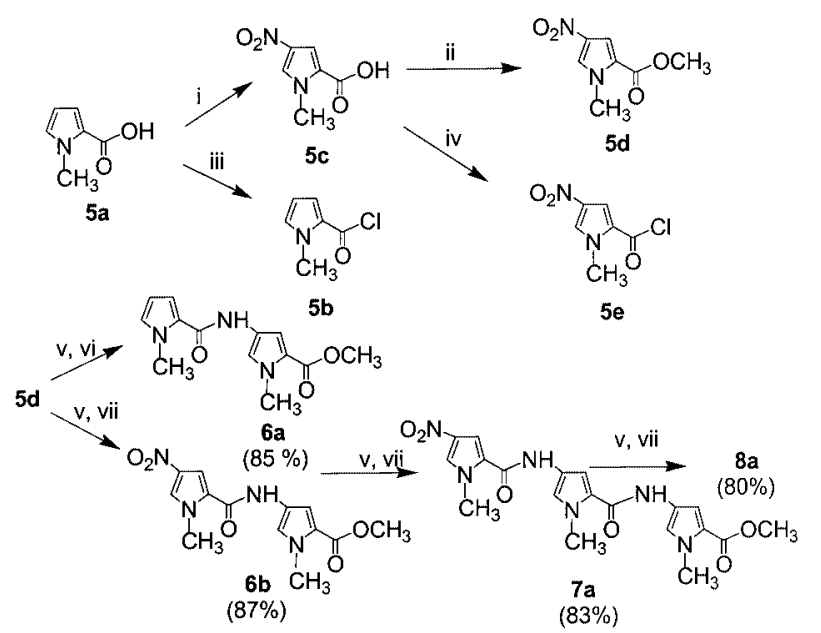

Scheme 1. Reagents conditions and yields: (i) $\mathrm{HNO}_{3} / \mathrm{Ac}_{2} \mathrm{O},-25$ ${ }^{\circ} \mathrm{C}, 30 \mathrm{~min}(40 \%)$ (ii) $\mathrm{MeOH} / \mathrm{H}_{2} \mathrm{SO}_{4}$ (cat.), reflux, $12 \mathrm{~h}(95 \%)$ (iii) $\mathrm{SOCl}_{2}$, THF, $0{ }^{\circ} \mathrm{C}, 1 \mathrm{~h}$, then room temp., $30 \mathrm{~min}$; (iv) $\mathrm{SOCl}_{2}$, THF, reflux, $1 \mathrm{~h}$; (v) $\mathrm{H}_{2}-\mathrm{Pd} / \mathrm{C}(5 \%), 1 \mathrm{~atm}$, room temp., $18 \mathrm{~h}$; (vi) 5 b, $\mathrm{Et}_{3} \mathrm{~N},-5{ }^{\circ} \mathrm{C}, 1 \mathrm{~h}$, then $1 \mathrm{~h}$ at room temp. (vii) $5 \mathrm{e}, \mathrm{Et}_{3} \mathrm{~N},-5{ }^{\circ} \mathrm{C}$, $1 \mathrm{~h}$, then $1 \mathrm{~h}$ at room temp.

It is important to note that all the intermediate nitro compounds containing 2-4 pyrrole units were insoluble in most common organic solvents except for DMF and DMSO, and that this allowed their isolation in pure form just by successive washing with $5 \% \mathrm{NaHCO}_{3}, 2 \mathrm{~N} \mathrm{HCl}$ and $\mathrm{MeOH}$, without requiring the use of column chromatography. Use of $\mathrm{NaHCO}_{3}$ as the base as reported previously ${ }^{[14 b]}$ requires the use of water as the co-solvent in the coupling reactions, and this method gave poor yields $(\approx 40 \%)$ in our hands. All the reductions were performed in dry $\mathrm{DMF}^{[14 \mathrm{~b}]}$ rather than in methanol, ${ }^{[14 \mathrm{c}]}$ which allowed the corresponding "unstable" amines to be coupled as soon as they had been filtered from the $\mathrm{Pd} / \mathrm{C}$, avoiding the need for the evaporation of the solvent. Use of $\mathrm{Hu}-$ nig's base ${ }^{[14 c]}$ did not offer any additional advantage over $\mathrm{Et}_{3} \mathrm{~N}$ as far as coupling yields are concerned, and we therefore used the latter reagent for all the acid chloride-
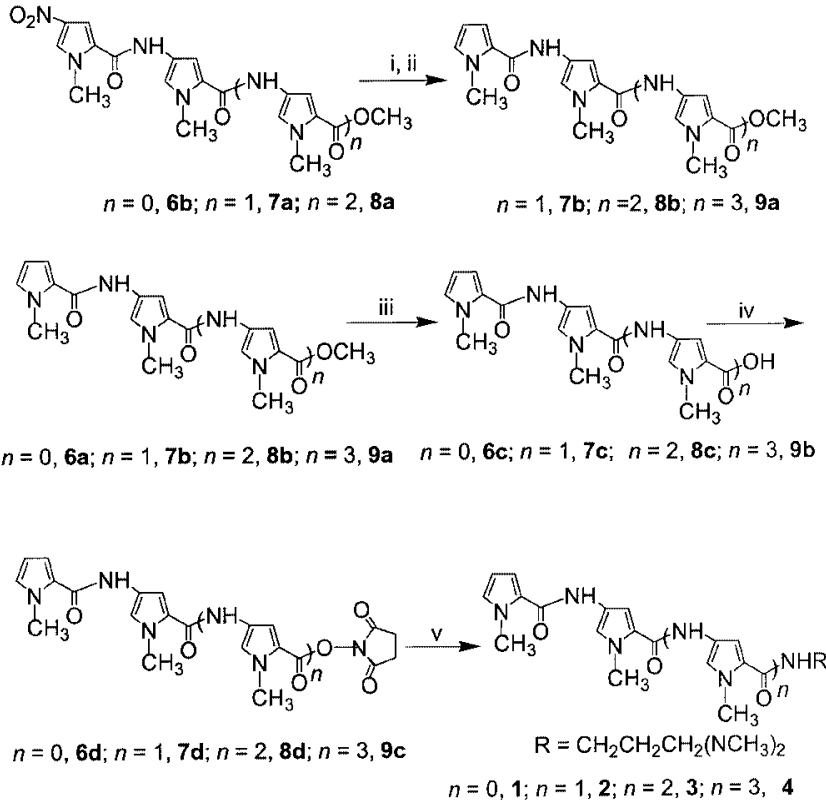

Scheme 2. Reagents conditions and yields: (i) $\mathrm{H}_{2}-\mathrm{Pd} / \mathrm{C}(5 \%), 1 \mathrm{~atm}$, room temp., $18 \mathrm{~h}$; (ii) $5 \mathrm{~b}, \mathrm{Et}_{3} \mathrm{~N},-50{ }^{\circ} \mathrm{C}, 1 \mathrm{~h}$, then $1 \mathrm{~h}$ at room temp. (80, 78 and $85 \%$ for $7 \mathbf{b}, \mathbf{8 b}$ and $9 \mathbf{a}$, respectively); (iii) $0.25(\mathrm{~N})$ $\mathrm{NaOH}, \mathrm{EtOH} / \mathrm{H}_{2} \mathrm{O}$, reflux, $1 \mathrm{~h}$, then $0{ }^{\circ} \mathrm{C}, 0.5$ (N) $\mathrm{HCl}(96,94,92$ and $90 \%$ for $\mathbf{6 c}, \mathbf{7 c}, \mathbf{8 c}$ and $\mathbf{9 b}$, respectively; (iv) DCC, HOSu, DMF, $0{ }^{\circ} \mathrm{C}, 30 \mathrm{~min}$, then room temp., $4 \mathrm{~h}$; (v) $N, N$-dimethyl-1,3-diaminopropane, room temp., $2 \mathrm{~h}(80,88,90$ and $82 \%$ for $\mathbf{1}-\mathbf{4}$ respectively)

amine coupling reactions. The reaction time for the generation of 1-methyl-4-nitro-1 $H$-pyrrole-2-carbonyl chloride (5e) was optimized to ca. $1 \mathrm{~h}$. We did not observe any decomposition of the acid chloride, as reported earlier. Shorter reaction times $(5 \mathrm{~min})$ gave poor yields of the coupling products, presumably due to incomplete conversion of the acid to the acid chloride. After the ' $N$-terminus capping', all the poly- $N$-methylpyrrole-based peptide derivatives turned out to be soluble in common organic solvents such as chloroform, ethyl acetate or methanol. The corresponding acids could easily be attached to a variety of amines either by DCC-mediated coupling or through the intermediacy of the corresponding succinimide esters (not shown). The (dimethylamino)propionami$\mathrm{de}^{[14 \mathrm{~h}]}$ group was chosen at the $C$-terminus rather than the amidine group present in Dst on account of its optimal solubility, ease of synthesis and also its amenability for further functionalization: by quaternization with appropriate bioactive molecules, for example. All the final compounds were soluble in organic solvents in their free base forms. The dimethylaminopropionamide group was introduced only in the last step of synthesis, because of our observation that the $\mathrm{N}$-terminus free amines with this group at the $C$-terminus were considerably less stable than those with methyl esters at their $C$-termini. All the final compounds and those intermediates that were stable upon isolation were fully characterized by ${ }^{1} \mathrm{H}$ and ${ }^{13} \mathrm{C}$ NMR, FT-IR, mass spectrometry and elemental analysis (cf. Exp. Sect.). 


\section{DNA-binding Studies}

\section{Interaction with AT-Based Sequences}

Small DNA-binding molecules such as Dst, Nt and spermine derivatives are known to stabilize the doublestranded form of DNA ( $d s$-DNA), and hence increase the double helix-to-random coil transition ('melting') temperature $\left(T_{m}\right)$ of DNA. ${ }^{[5][5 b][5 e]}$ Thermally induced DNA melting in the presence of various oligopeptides was monitored by following the UV absorbance of DNA at $260 \mathrm{~nm}$. The results of the $T_{m}$ measurements are presented in Table 1. It is important to note that there was no enhancement in $T_{m}$ in the case of D2 (1), suggesting that the presence of a minimum of three pyrrole rings is necessary to provide at least a minimal binding with DNA. Moreover, there is a sudden jump in $\Delta T_{m}$ as the number of pyrrole rings increases from three to four. This is also true in the case of apparent binding constants $K_{\text {app }}$ (see below). None of the oligopeptides showed any enhancement in the $T_{m}$ of poly $\mathrm{d}(\mathrm{GC})$ under identical conditions $(40 \mathrm{~mm} \mathrm{NaCl},[\mathrm{D}] /[\mathrm{P}]=0.2$.

$[\mathrm{D}] /[\mathrm{P}]=[$ Ligand $] /[\mathrm{DNA}]$, where $[\mathrm{DNA}]$ is the concentration of DNA expressed in nucleotide phosphates, i.e. base molarity).

The apparent binding constants of the oligopeptides D3-D5 (2-4) were then estimated by ethidium bromide $(\mathrm{EBr})$ displacement assay. Effective binding of a nonintercalative molecule to DNA would displace $\mathrm{EBr}$ from $d s$ DNA and result in the quenching of its fluorescence emission. ${ }^{[16 a][16 b]}$ From the concentration of such a molecule (ligand) required for the quenching of $\mathrm{EBr}$ fluorescence to $50 \%$ of its original value, the apparent binding constant $\left(K_{\text {app }}\right)$ of the ligand can be calculated, by the Equation given in the Exp. Sect. ${ }^{[16 a]}$ It may be noted that the $K_{\text {app }}$ values were found to be higher for poly d(AT) and poly dA. poly dT than for CT DNA. Moreover, for a given DNA sequence, the $K_{\text {app }}$ values increase as a function of peptide chain length.

Footprinting experiments are often employed to identify the binding sites of small molecules on DNA. ${ }^{[17 a]}$ In this case, footprinting experiments were performed in order to confirm the sequence-specific nature of the binding of the oligopeptides D3-D5. A positively charged metal complex of an ethylenediamine salicylidine derivative [Figure 2, c)] developed in our laboratory ${ }^{[17 \mathrm{~b}, 17 \mathrm{c}]}$ was used as the DNAcleaving agent in these experiments. This reagent, in the presence of dithiothreitol (DTT), produced rapid, practically sequence-neutral scission of DNA, and so was used to decipher footprints of small molecules that bind to DNA. Such experiments revealed that all three oligopeptides (D3-D5) did indeed complex to AT-rich sites on the $1.15 \mathrm{~kb}$ long ${ }^{32} \mathrm{P}$-end labeled DNA fragment (Figure 2). The regions protected by the oligopeptides, which fell in the resolving region of the autoradiogram, are shown in Figure 2, b). Thus, it may be inferred from the footprinting analysis that these modified oligopeptides have preserved the ATspecific binding exhibited by the parent compound Dst; such a conclusion is in agreement with the data obtained from the $\Delta T_{m}$ measurements and $K_{\text {app }}$ determination based on $\mathrm{EBr}$ displacement assay.

Neither the free polyamides nor the DNA duplexes used exhibited any $\mathrm{CD}$ signals in the ligand absorption region. However, upon addition of peptides D3-D5 to poly d(AT), poly dA. poly dT and CT DNA, substantial induced CD signals (ICD) arise in the 300-380 region. The CD signal observed in this case is characterized by two ICD maxima with positive and negative amplitudes centred around $350 \mathrm{~nm}$ and $280 \mathrm{~nm}$, respectively (Figure 3 and Figure 4). The exact positions of the ICD maxima and minima and their amplitudes were characteristic of each peptide/DNA pair. Since this induced Cotton effect is outside the CD spectrum of DNA, it directly reflects the environment due to bound ligand molecules. The sign and magnitude of ICD signals have often been used to compare the binding modes of small molecules to DNA sequences. ${ }^{[5 e, 16,18]}$

Notably, D2 did not exhibit any ICD under similar conditions. The absence of any detectable ICD in the case of D2 is indicative of the absence of interaction between this peptide and DNA. This important observation, in agreement with the results of $T_{m}$ measurements, again suggests that a minimum of three pyrrole rings is necessary for the onset of DNA binding in the case of 'all pyrrole' polyamides lacking the leading amide unit.

To a first approximation, for a given ligand/DNA pair, the ICD magnitude can be taken as an indication of the extent of binding. Therefore, the saturation in the ICD sig-

Table 1. Summary of melting temperature measurements ${ }^{[\mathrm{a}]}$ and apparent binding constant measurements ${ }^{[\mathrm{b}]}$

\begin{tabular}{|c|c|c|c|c|c|c|}
\hline \multirow[t]{2}{*}{ Peptide ${ }^{[a][b]}$} & \multicolumn{2}{|c|}{ poly dA. poly dT } & \multicolumn{2}{|c|}{ poly d(A.T) } & \multicolumn{2}{|l|}{ CT DNA } \\
\hline & $\Delta T_{m}\left({ }^{\circ} \mathrm{C}\right)$ & $K_{\mathrm{app}}\left(\mathrm{M}^{-1}\right)$ & $\Delta T_{m}\left({ }^{\circ} \mathrm{C}\right)$ & $K_{\mathrm{app}}\left(\mathrm{M}^{-1}\right)$ & $\Delta T_{m}\left({ }^{\circ} \mathrm{C}\right)$ & $K_{\text {app }}\left(\mathrm{M}^{-1}\right)$ \\
\hline 2 & 4.4 & $1.6 \times 10^{6}$ & 0.5 & $4.2 \times 10^{5}$ & 0 & $5.8 \times 10^{4}$ \\
\hline 3 & 15.4 & $6.3 \times 10^{7}$ & 11.0 & $3.3 \times 10^{7}$ & 1.6 & $1.0 \times 10^{6}$ \\
\hline 4 & 25.0 & $9.2 \times 10^{7}$ & 26.0 & $1.2 \times 10^{8}$ & 4.0 & $4.5 \times 10^{6}$ \\
\hline $\operatorname{Distamycin}^{[\mathrm{c}]}$ & & & & $3.5 \times 10^{7}$ & & $7.7 \times 10^{6}$ \\
\hline
\end{tabular}

[a] $40 \mathrm{~mm} \mathrm{NaCl}, 10 \mathrm{~mm}$ tris $\cdot \mathrm{HCl}(\mathrm{pH}=7.4),[\mathrm{D}] /[\mathrm{P}]=0.2 .{ }^{[\mathrm{b}]} 40 \mathrm{~mm} \mathrm{NaCl}, 10 \mathrm{~mm}$ tris $\cdot \mathrm{HCl}(\mathrm{pH}=7.4) .{ }^{[c]}$ See ref. ${ }^{[16]}$. Dst has been shown to have similar binding affinity for poly d(A.T) and poly dA. poly dT (ref. ${ }^{[4 a]}$ ). 
(a)

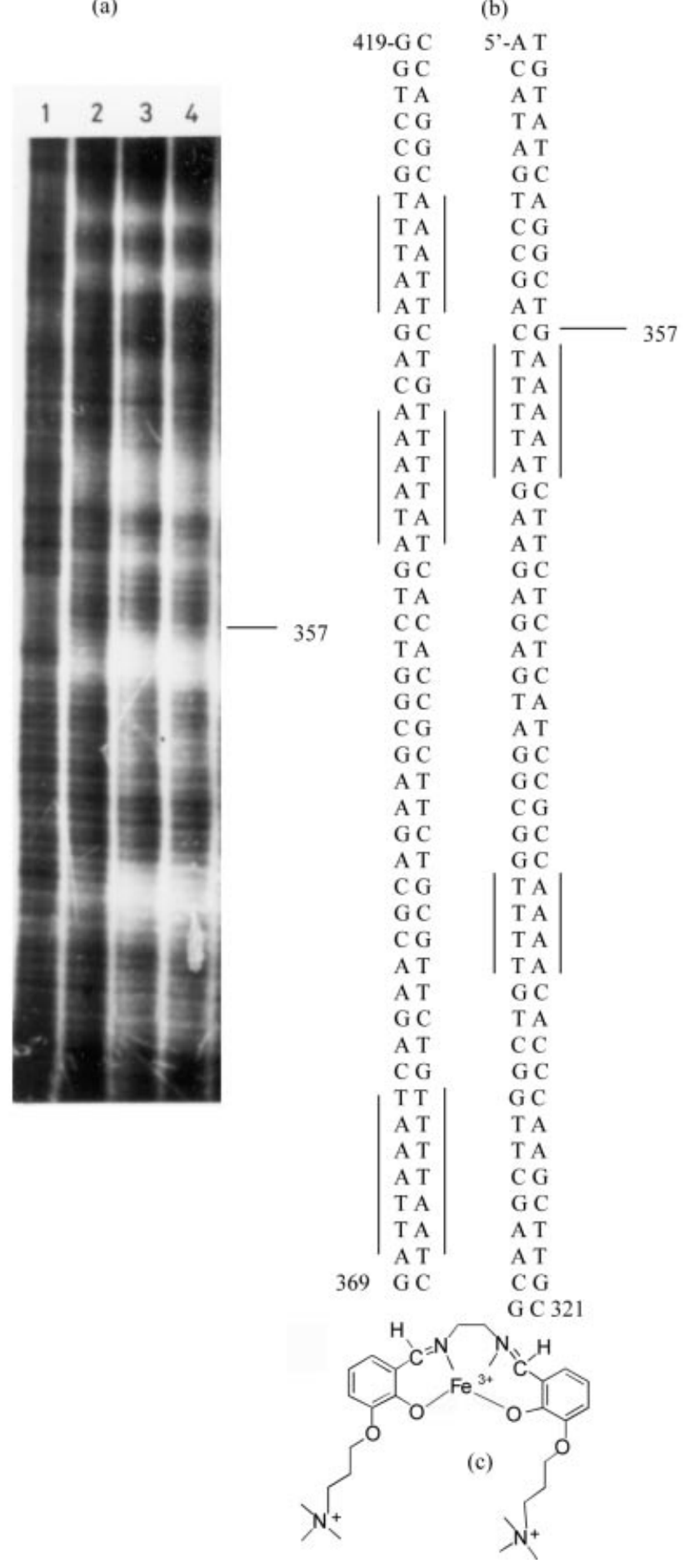

Figure 2. (a) Footprints of D3-D5 on DNA; Lane '1': DNA treated with $20 \mu \mathrm{M}$ of $\mathrm{Fe}^{\mathrm{III}}$ salen +DTT; Lane '2', DNA incubated with 50 $\mu \mathrm{M}$ of $\mathbf{D 3}$ and then treated with $20 \mu \mathrm{M}$ of $\mathrm{Fe}^{\mathrm{III}}$ salen+DTT; Lanes ' 3 ' and '4': DNA incubated with $10 \mu \mathrm{M}$ of D4 or D5 respectively, and then treated with $20 \mu \mathrm{M}$ of Fe $\mathrm{Fe}^{\mathrm{III}}$ salen+DTT; (b) DNA sequence corresponding to the resolving region of the gel in (a); base 357 marks the beginning of one of the A/T rich sites $(358-362)$; (c) chemical structure of $\mathrm{Fe}^{\mathrm{III}}$ salen

nal can be used for the estimation of the ligand/duplex stoichiometry. The observed ICD signal saturated in all the cases mentioned above at $[\mathrm{D}] /[\mathrm{P}]$ ratios characteristic of
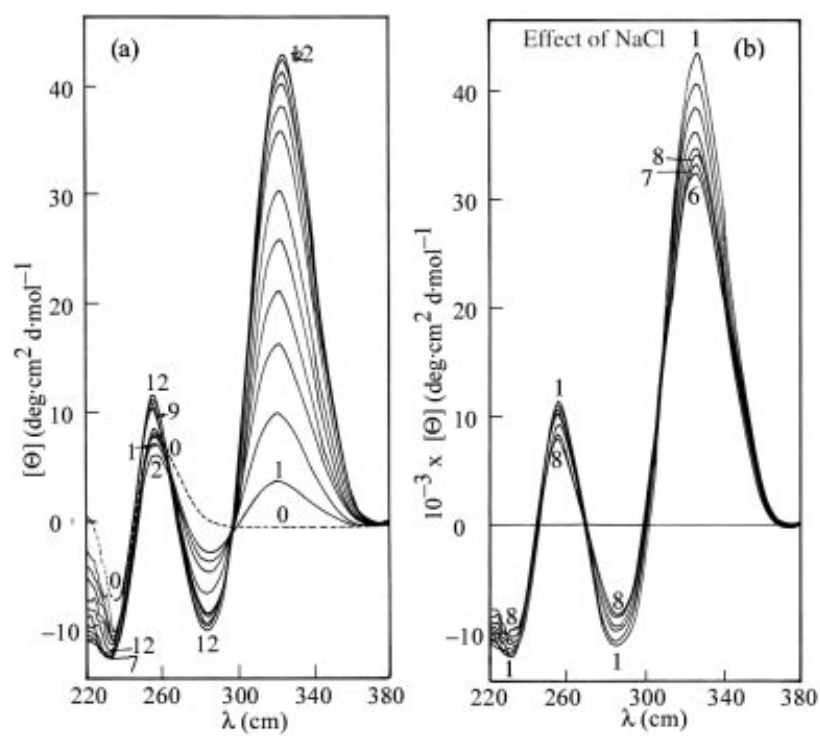

Figure 3. (a) CD spectra of the complex of D4 with poly d(AT); trace ' 0 ' corresponds to the CD spectrum of free poly d(AT); experiments were performed in $10 \mathrm{~mm}$ tris $\cdot \mathrm{HCl}$ buffer $(\mathrm{pH}=7.4)$ containing $40 \mathrm{~mm} \mathrm{NaCl}$; [poly d(AT)] $=29.1 \mu \mathrm{M}$; each addition of D4 caused an increase in the $[\mathrm{D}] /[\mathrm{P}]$ by 0.021 ; at ' 12 ' the $[\mathrm{D}] /[\mathrm{P}]$ ratio reached 0.26 ; (b) effect of addition of $[\mathrm{NaCl}]$ on the $\mathrm{CD}$ spectra of D4/ poly d(AT) presented in panel (a); spectrum ' 1 ' is the same as spectrum ' 12 ' in panel (a); with each successive addition (traces ' 2 ' to ' 8 '), $[\mathrm{NaCl}]$ was increased as follows: $0.1,0.2,0.4$, $0.8,1.6,3.2$ and $4.8 \mathrm{M}$, respectively; note that the ordinate has been multiplied by $10^{-3}$ in the case of (a)
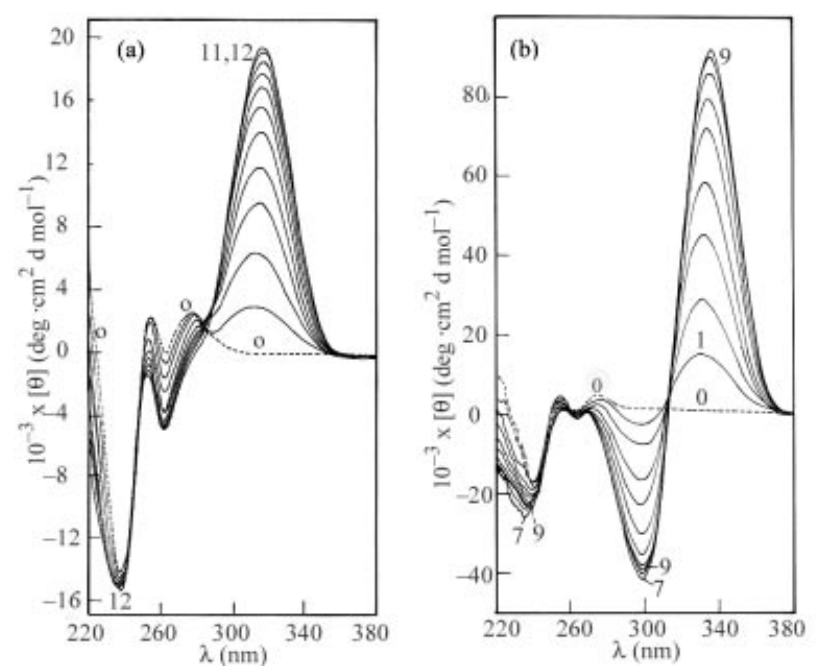

Figure 4. CD spectra of the complexes of D3 and D5 with poly dA. poly dT; trace ' 0 ' corresponds to the CD spectrum of free poly dA. poly dT in both the panels; experiments were performed in $10 \mathrm{~mm}$ tris $\cdot \mathrm{HCl}$ buffer $(\mathrm{pH}=7.4)$ containing $40 \mathrm{~mm} \mathrm{NaCl}$; [poly dA. poly dT $]=43.8 \mu \mathrm{M}$; each addition of $\mathbf{D 3}$ caused an increase in the $[\mathrm{D}] /[\mathrm{P}]$ by 0.025 ; at ' 12 ' the $[\mathrm{D}] /[\mathrm{P}]$ ratio was 0.26 ; (b) [poly dA. poly dT $]=20.3 \mu \mathrm{M}$; each addition of $\mathbf{D 5}$ caused an increase in the $[\mathrm{D}] /[\mathrm{P}]$ by 0.019 ; at ' 9 ' the $[\mathrm{D}] /[\mathrm{P}]$ ratio was 0.188

each ligand/duplex type. The general trend was a decrease in the saturation value of $[\mathrm{D}] /[\mathrm{P}]$ with the increase in the number of pyrrole rings in the peptide sequence. Moreover, the magnitude of the observed ICD signal increased with the number of pyrrole units in the oligopeptide. It appears 
that the number of chromophore (pyrrole carboxamide) residues contribute to the intensity and location of the negative and positive ICD bands. From the saturation $[\mathrm{D}] /[\mathrm{P}]$ values it was possible to estimate the stoichiometry of binding, and this is consistent with a 2:1 head-to-tail overlapped model, as has been observed in the case of Dst ${ }^{[3 \mathrm{c}, 19]}$ and $\mathrm{Im} /$ Py polyamides. ${ }^{[20]}$

\section{Interaction with Poly d(GC)}

A steric clash between the pyrrole $\mathrm{C}(3) \mathrm{H}$ and the guanine $\mathrm{C}(2) \mathrm{NH}_{2}$ has been suggested as the reason for the avoidance of GC sites by Dst and Nt. However, it was seen that Dst also exhibited ICD signals with GC-containing sequences. ${ }^{[a, 10]}$ These ICD signals were, however, found to be highly susceptible to increases in the $\mathrm{NaCl}$ concentration, the susceptibility of ICD to $[\mathrm{NaCl}]$ varying directly with the GC content. The nature of interactions existing between poly $\mathrm{d}(\mathrm{GC})$ and Dst has not yet been established. Initially it was proposed that the amide carbonyls of Dst act as hydrogen bond acceptors for the $\mathrm{C}(2) \mathrm{NH}_{2}$ of guanine. ${ }^{[5]}$ Fluorescence titrations involving poly $\mathrm{d}(\mathrm{GC})$ and dansylated Dsts had shown that the binding affinity of such Dsts for poly $\mathrm{d}(\mathrm{GC})$ is approximately three orders of magnitude lower than that of poly d(AT) and poly dA. poly dT. ${ }^{[5 \mathrm{~d}]} \mathrm{It}$ was proposed that weak hydrogen bonds exist between amide NHs and the N(3) of adenine and the $\mathrm{O}(2)$ of thymine, a situation similar to that of AT sequences. Recently, it was reported that Dst and Net bind to G-quadruplexes. ${ }^{[8 b]}$ While Dst binds to two of the four grooves in a 2:1 antiparallel overlapped fashion, Net binding involves single molecules occupying each of the four grooves. The nature of the molecular interactions involved in these cases, however, is not yet established. These results suggest that the interaction of Dst analogues with GC-rich sequences of DNA merits further investigation, which would be important in terms of their future applications in precise genetic targeting of DNA sequences in vivo.

Peptide D3 (2) exhibited an ICD band that appeared as a "shoulder" on the intrinsic positive CD band of poly $\mathrm{d}(\mathrm{GC})$. There were marked changes in the intrinsic $C D$ band of DNA as well [Figure 5, a]. The positive CD band increased in intensity, while the negative $\mathrm{CD}$ band underwent a progressive suppression as a function of [peptide]/ [DNA] ratio. Compound D4 (3), on the other hand, exhibited intense positive ICD bands similar to those seen in the case of poly d(AT) and poly dA. poly dT [Figure 5,b)]. The magnitude of ICD, however, was about four times higher in the case of poly d(GC). Peptide D5 (4), which possesses five pyrrolecarboxamide units, exhibited interesting behavior. At low [peptide]/[DNA] ratios $(<0.13)$, the ICD in the $300-370 \mathrm{~nm}$ region was positive [Figure 5,c), curves 1 and 2], but this transformed into a negative band at higher [D]/ $[\mathrm{P}]$ ratios $[>0.13$, Figure 5, c), curves 5-10]. There was a concomitant pronounced enhancement in the intrinsic $\mathrm{CD}$ band of poly $\mathrm{d}(\mathrm{GC})$ as well. Thus, the magnitude and nature of ICD bands depended on the number of pyrrolecarboxamide units. This was in contrast to the behavior of these compounds with poly d(AT) and poly dA. poly dT.
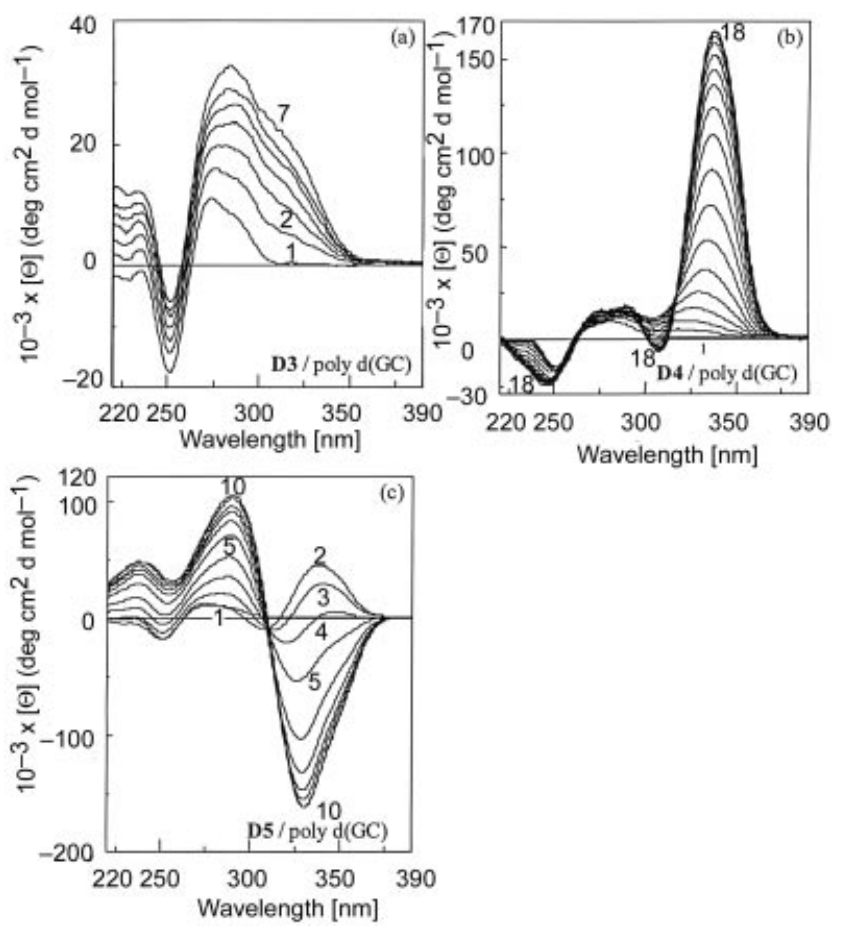

Figure 5. CD spectra of the complexes of D3-D5 (2-4) with poly $\mathrm{d}(\mathrm{GC})$; experiments were performed in $10 \mathrm{~mm}$ tris $\cdot \mathrm{HCl}$ buffer containing $40 \mathrm{~mm} \mathrm{NaCl}(\mathrm{pH}=7.4)$; [poly $\mathrm{d}(\mathrm{GC})]=20.17 \mathrm{~mm}$; increasing amounts of the peptides were added to a constant concentration of poly $d(G C)$ in all the cases; in panels (a)-(c), the $[D] /[P]$ ratio corresponding to traces ' $18^{\prime}$ ', ' $10^{\prime}$ ' and ' 7 ' was 2.3 ; see Figure 6 for the effect of $\mathrm{NaCl}$ on these ICD spectra

The ICD spectra in the $310-370 \mathrm{~nm}$ region were always positive in these cases, irrespective of the number of pyrrolecarboxamide units. There was an additional negative band in the $280-320 \mathrm{~nm}$ region. The intensity of this band varied with the number of pyrrolecarboxamide units. The higher the number of pyrrolecarboxamide units, the greater was the ICD intensity.

\section{Effect of Salt on ICD}

The effect of increasing $[\mathrm{NaCl}]$ on the ICD spectra of the complex of D4 (3) and poly d(AT) is shown in Figure 3, b). When $[\mathrm{NaCl}]$ was increased from $40 \mathrm{~mm}$ to $1.6 \mathrm{M}$, there was a gradual suppression of ICD to about $70 \%$ of its initial value. Complexes of D3 (2) were more prone to salt-induced dissociation than those of D4, while those of D5 (4) were more resistant. It may be noted that a slight enhancement in ICD was observed above $1.6 \mathrm{M} \mathrm{NaCl}$ [Figure 3, b)]. Complexes of D5 showed no such enhancement, while those of D3 showed a greater enhancement than seen with those of D4 (not shown). The observed enhancement in ICD may be due to 'reassociation' of the dissociated ligand molecules or due to an increase in the ICD of the ligands still bound to DNA when the 'naked regions' of DNA undergo a conformational change at very high salt concentrations. The intense ICD signals observed in the case of D4 and D5 with poly $\mathrm{d}(\mathrm{GC})$ transformed into a new band of lower intensity when the $[\mathrm{NaCl}]$ was raised to $100 \mathrm{~mm}$. This was a positive 
band that appeared as a shoulder on the intrinsic CD band. The intrinsic DNA band itself exhibited substantial differences. The positive band was about seven times more intense than for free DNA, and the negative band was suppressed to ca. $20 \%$ of its original intensity. These ICD bands were similar to the ICD bands observed in the case of D3. They were resistant to further increase in ionic strength, until $[\mathrm{NaCl}]=1.6 \mathrm{M}$. Beyond this $[\mathrm{NaCl}]$, the DNA band underwent a B-Z type transition, with the ICD band still intact. The $\mathrm{CD}$ spectra of the $\mathrm{B}$ and $\mathrm{Z}$ forms of DNA have a 'mirror image' relationship [see d) in Figure 6]. It may be noted that the $\mathrm{CD}$ spectra of the complexes of D3-D5 at 3.2 or $4.8 \mathrm{M} \mathrm{NaCl}$ in the intrinsic $\mathrm{CD}$ region of DNA are similar to the curve ' 2 ' presented in Figure 6 [see d)]. The $\mathrm{CD}$ bands obtained in these cases do not correspond exactly with that of free poly $\mathrm{d}(\mathrm{GC})$ at $4.8 \mathrm{M} \mathrm{NaCl}$, apparently due to the contributions from ICD in this region.

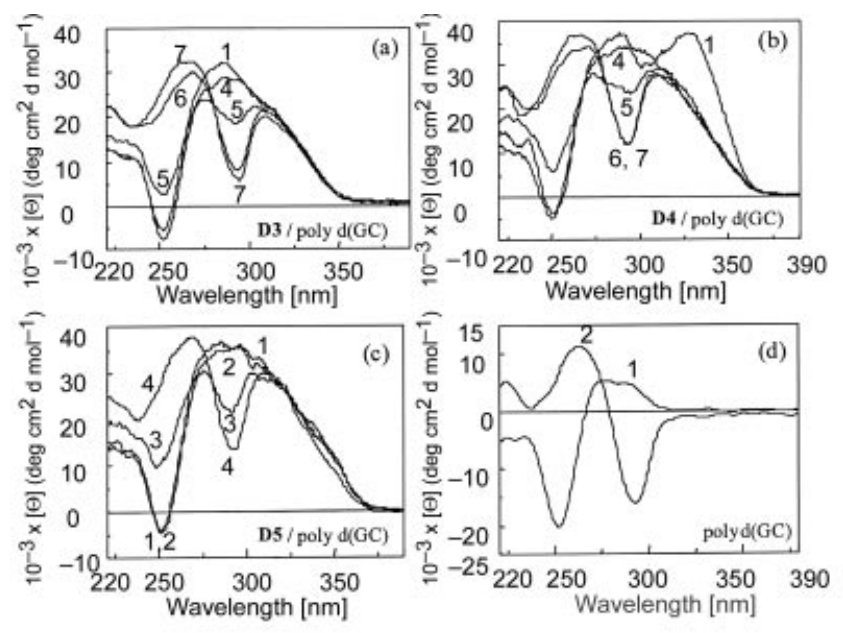

Figure 6. Effect of $[\mathrm{NaCl}]$ on the $\mathrm{CD}$ spectra of the complexes of D3-D5 (2-4) with poly d(GC); experiments were performed in $10 \mathrm{~mm}$ tris $\cdot \mathrm{HCl}$ buffer $(\mathrm{pH}=7.4)$; [poly $\mathrm{d}(\mathrm{GC})]=20.17 \mu \mathrm{M}$; increasing amounts of $[\mathrm{NaCl}]$ was added to preformed complexes of D3-D5 formed at $40 \mathrm{~mm} \mathrm{NaCl}$; with successive additions, the [ $\mathrm{NaCl}]$ varied as follows: $0.1,0.2,0.4,0.8,1.6,3.2$ and $4.8 \mathrm{~m}$; (a) \& (b) the $[\mathrm{D}] /[\mathrm{P}]$ ratios were 2.3 ; the $[\mathrm{NaCl}]$ corresponding to traces ' 1 ', ' 4', '5', '6 and '7' were $100 \mathrm{~mm}, 0.8 \mathrm{M}, 1.6 \mathrm{M}, 3.2 \mathrm{~m}$ and 4.8 $\mathrm{M}$ respectively in both cases; (c) the $[\mathrm{D}] /[\mathrm{P}]$ ratio was $2.3 ;[\mathrm{NaCl}]$ corresponding to traces ' 1 ' , ' 2 ', ' ' 3 ' and ' 4 ' were $100 \mathrm{~mm}, 1.6 \mathrm{M}, 3.2$ $\mathrm{M}$ and $4.8 \mathrm{M}$, respectively; (d) effect of $\mathrm{NaCl}$ on the $\mathrm{CD}$ spectrum of free poly d(GC); $[\mathrm{NaCl}]$ corresponding to traces ' 1 ' and ' 2 ' were $40 \mathrm{~mm}$ and $4.8 \mathrm{~m}$ respectively

The nature of these complexes is intriguing. Crystallographic and NMR evidence shows that DNA is preserved in the B form in its complexes with minor groove binders

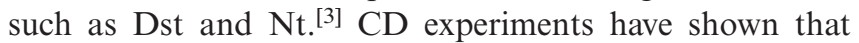
intercalators such as EBr stabilize the B form of DNA, and that DNA existing in other morphs such as the $\mathrm{Z}$ forms undergoes a transition to the $\mathrm{B}$ form in the presence of

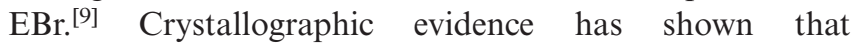
DNA-RNA chimers are converted from the A form into the $\mathrm{B}$ form on binding to Dst. ${ }^{[19]} \mathrm{A}$ Z-to-B transition of DNA secondary structure has been reported on addition of Dst and Net to the left-handed form of poly d(AT) produced upon addition of $5 \mathrm{M} \mathrm{NaCl}$ and $95 \mathrm{~mm} \mathrm{Ni}\left(\mathrm{ClO}_{4}\right)_{2} \cdot{ }^{[10 \mathrm{c}]}$
In the case of poly d(GC), however, there has been no consensus in terms of Z-B transition. ${ }^{[10,11]}$ It has been suggested that the binding of $\mathrm{Nt}$ and Dst to the $\mathrm{Z}$ morph of poly d(GC) produced in the presence of hexaamine cobalt chloride gives no clear evidence in favor of B-to-Z transition. ${ }^{[1]}$ The non-B-to-B transition of DNA is judged, for example, from the appearance of ICD with concomitant changes in the intrinsic DNA CD spectrum when a minor groove binder such as Dst or an intercalator such as $\mathrm{EBr}$ is added to a solution of the altered B form of DNA. ${ }^{[9,10 b, 11]}$ In the current case, the ICD bands were present even after the B-to-Z transition of DNA (Figure 6). This would imply that the complex is such that, possibly, similar interactions are maintained with both B and Z (or Z-like) forms of DNA. In the presence of D3-D5 (2-4), DNA appears to undergo a B-to-Z type transition, preserving the ICD (Figure 6). This suggests that D3-D5 do indeed bind the $Z$ form of DNA. Studies by Rao et al. involving the $\mathrm{Z}$ morph of poly $\mathrm{d}(\mathrm{GC})$ produced in the presence of $30 \mathrm{~mm}$ of hexamine cobalt chloride (HCC) have shown that addition of Dst or Net to poly d(GC) in the presence of HCC produces positive ICD around the $300-350 \mathrm{~nm}$ region, without significant alterations in the DNA part of the spectrum. ${ }^{[1]}$

\section{Conclusions}

A simple and general procedure for the solution-phase synthesis of four Dst analogues without the leading amide unit at their $N$-termini has been developed. DNA-binding studies with these oligopeptides showed that a minimum of three pyrrolecarboxamide units is necessary for the onset of DNA binding. Footprinting analysis showed that the remaining three molecules bound to AT-rich regions on DNA. Binding constant measurements and DNA melting temperature analysis indicated that the binding affinity was higher for poly d(AT) and poly dA.poly dT than for CT-DNA. Despite these observations, intense ICD signals were observed in the case of poly $\mathrm{d}(\mathrm{GC})$. Though these ICD signals were highly susceptible to changes in salt concentration, residual ICD was observed at $\mathrm{NaCl}$ concentrations as high as $1.6 \mathrm{M}$, persisting even at $4.8 \mathrm{~m} \mathrm{NaCl}$, even after DNA had undergone a B-to-Z type transition, as judged by the changes in the intrinsic CD spectrum of DNA. This indicated that these "all pyrrole" analogues of Dst maintain interactions with poly $\mathrm{d}(\mathrm{GC})$ that are not entirely of electrostatic origin. That ICD is preserved even after DNA has undergone a B-Z type transition indicates that these molecules are able to bind to $\mathrm{Z}$ form DNA as well. The binding of these molecules to poly d(GC) is also significant in the context of the recent report that Dst binds to G-quadruplets with a 2:1 antiparallel orientation in each of the four grooves. Such an antiparallel mode of binding has been well characterized in the case of AT sites. Such complexes are stabilized by the 'bifurcated' hydrogen bonds between the peptide molecules and the DNA minor groove, and also the stacking interactions between the amide residues and the aromatic pyrrole rings of the overlapping monomers. The 
nature of interactions involved in the complexes of Dst and analogues with GC sequences, both in the case of G-quadruplexes and duplexes, and in the current case, is intriguing and merits further investigation. Characterization of the interaction of polyamide-based minor groove binders with the 'noncognate' sites would be important in the context of eventual utility in medicinal applications.

\section{Experimental Section}

General: Melting points were recorded on a Mettler model FP1 or a Büchi model B540 melting point apparatus. Melting points are uncorrected. ${ }^{1} \mathrm{H}$ and ${ }^{13} \mathrm{C}$ NMR were recorded on JEOL JNM $\lambda$ $300\left(300 \mathrm{MHz}\right.$ for ${ }^{1} \mathrm{H}$ and $75 \mathrm{MHz}$ for ${ }^{13} \mathrm{C}$ ), Bruker AMX 400 $\left(400 \mathrm{MHz}\right.$ for ${ }^{1} \mathrm{H}$ and $100.6 \mathrm{MHz}$ for ${ }^{13} \mathrm{C}$ ), or Bruker DRX 500 $\left(500 \mathrm{MHz}\right.$ for ${ }^{1} \mathrm{H}$ and $125 \mathrm{MHz}$ for ${ }^{13} \mathrm{C}$ ) spectrometers. Chemical shifts $(\delta)$ are reported in ppm downfield from the internal standard, TMS in the case of proton NMR. ${ }^{13} \mathrm{C} \mathrm{NMR:} \mathrm{CDCl}_{3}$ as solvent, $\delta_{\mathrm{C}}=77.1 \mathrm{ppm},\left[\mathrm{D}_{6}\right] \mathrm{DMSO}$ as solvent, $\delta_{\mathrm{C}}=39.60 \mathrm{ppm}$. IR spectra were recorded on a Perkin-Elmer 781 spectrometer or on a JASCO FT-IR 410 instrument. Mass spectra were recorded on a Kratos PCKompact SEQ V1.2.2 MALDI-TOF spectrometer or a HP LCMSD 1100 electrospray ionization (ESI MS) spectrometer. Eluents for column chromatography $\left(\mathrm{MeOH}, \mathrm{EtOAc}, \mathrm{CHCl}_{3}\right.$ and petroleum ether (60-80 fraction)) were distilled before use. Solvents used for reactions were dried before use: $\mathrm{DMF}, \mathrm{CH}_{2} \mathrm{Cl}_{2}$ and $\mathrm{Et}_{3} \mathrm{~N}$ were dried over $\mathrm{P}_{2} \mathrm{O}_{5}, \mathrm{Et}_{3} \mathrm{~N}$ was stored over $\mathrm{KOH}$, and THF was dried over sodium benzophenone ketyl.

\section{Spectroscopy}

$T_{m}$ measurements were performed by following the changes in optical densities at $260 \mathrm{~nm}$ as a function of temperature. Experiments were performed in Quartz cuvettes stoppered with Teflon caps on a Beckman model 640 spectrophotometer fitted with a temperature controller. The samples were heated at a rate of $1{ }^{\circ} \mathrm{C} / \mathrm{min}$ and the absorbencies were recorded for every $0.5^{\circ}$ rise in temperature. [DNA] was $15 \mu \mathrm{M}$ (base molarity) for all the experiments. CD spectra were recorded either on a JASCO J-500A or on a JASCO J715 model spectropolarimeter. The CD values, expressed as molar ellipticity $[\theta]$, were calculated by the Equation $[\theta]=[100 \times \psi / l \times$ c] $\operatorname{deg} \cdot \mathrm{cm}^{2} \mathrm{dmol}^{-1}$, where $\psi$ is the observed ellipticity in degrees, $l$ is the path length of the cell in centimetres, and $c$ is the concentration of DNA in base molarity. All the binding experiments were carried out in $10 \mathrm{~mm}$ tris $\cdot \mathrm{HCl}$ buffer $(\mathrm{pH}=7.4)$ and at $25^{\circ} \mathrm{C}$. The salt concentrations were varied as indicated in the respective Figure legends. Fluorescence spectra were recorded on Hitachi model F4500 spectrofluorimeter, with excitation and emission band bass: $10 \mathrm{~nm}\left(\lambda_{e x}=525 \mathrm{~nm}, \lambda_{e m}=590 \mathrm{~nm}\right)$. Apparent binding constants $\left(K_{\text {app }}\right)$ of D3-D5 with $d s$-DNA were estimated and compared by measuring the loss of $\mathrm{EBr}$ fluorescence as a function of added ligand. ${ }^{[16]}$ The $K_{\text {app }}$ values were calculated from: $K_{\mathrm{EBr}}[\mathrm{EBr}]=$ $K_{\text {app. }}$ [Ligand], where [EBr] and $K_{\mathrm{EBr}}$ are the concentrations and binding constants of $\mathrm{EBr}$ respectively and [Ligand] is the concentration of ligand at $50 \%$ of maximal EBr fluorescence. The binding constant of $\mathrm{EBr}$ was taken to be $1 \times 10^{7} \mathrm{M}^{-1}$. [16]

\section{Footprinting}

\section{Preparation of 5'-End-Labeled DNA Fragment}

An $A T$-rich $1.15 \mathrm{~kb}$ fragment from pTrc99C plasmid was used for footprinting experiments. This fragment was PCR amplified with 3'-TGTGTAATATGCTCGGCCTTCGAATTA-5' (27 bp) as the forward primer and 5'-GTATGGCTTCATTCAGCTC-3' (19 bp) as the reverse primer. The forward primer $(6 \mathrm{pmol})$ was labelled with $\gamma\left[{ }^{32} \mathrm{P}\right]$-ATP $(30 \mu \mathrm{Ci})$ with 10 units of Polynucleotide Kinase (PNK) (NEB) in $1 \mathrm{X}$ PNK buffer. The PCR reaction mixture consisted of $6 \mathrm{pmol}$ each of the forward and reverse primers, $100 \mathrm{ng}$ of the plasmid template, $1.25 \mu \mathrm{L}$ of $10 \mathrm{~mm}$ dNTps, $5 \mu \mathrm{L}$ of $10 \mathrm{X}$ Taq DNA polymerase buffer with $\mathrm{MgCl}_{2}$ (Promega) and 2.5 units of Taq DNA Polymerase in a total reaction volume of $50 \mu \mathrm{L}$. This mixture was first heated for $2 \mathrm{~min}$ at $95^{\circ} \mathrm{C}$ and then subjected to 29 cycles of PCR. Each cycle consisted of 3 steps of incubation at $95{ }^{\circ} \mathrm{C}(1 \mathrm{~min}), 42{ }^{\circ} \mathrm{C}(1.5 \mathrm{~min})$, and $68{ }^{\circ} \mathrm{C}(2 \mathrm{~min})$ respectively. An extra incubation step at $68^{\circ} \mathrm{C}(10 \mathrm{~min})$ was added in the last cycle. The PCR product was run on agarose gel along with molecular weight markers and stained with $\mathrm{EBr}$. The $1.15 \mathrm{~kb}$ band was cut and eluted from the gel and subsequently purified by phenol/chloroform extraction procedures. The purified DNA was ethanol precipitated and kept at $-80{ }^{\circ} \mathrm{C}$ until use.

\section{Sequencing of the DNA Fragment by PCR}

The di-deoxy method (Sanger Method) was employed for sequencing the DNA fragment. End-labelling of the forward primer $(1 \mathrm{pmol})$ was achieved by use of 5 units of $P N K$ (NEB) in the procedure described above. A common mixture for PCR amplification was prepared by mixing $100 \mathrm{mg}$ of the plasmid template, $4.5 \mu \mathrm{L}$ of 10X Taq DNA polymerase buffer, 1 pmol of labelled primer and 2.5 units of Taq Polymerase in a total volume of $35 \mu \mathrm{L}$. This mixture was divided into four equal portions and mixed with $1.5 \mu \mathrm{L}$ of one of the four di-deoxy NTP solutions. The four tubes were subsequently heated for $3 \mathrm{~min}$ at $94{ }^{\circ} \mathrm{C}$ and subjected to 20 cycles of PCR. Each cycle consisted of three incubation steps: at $95{ }^{\circ} \mathrm{C}$ $(30 \mathrm{~s}), 55^{\circ} \mathrm{C}(30 \mathrm{~s})$ and $70{ }^{\circ} \mathrm{C}(1 \mathrm{~min})$ respectively.

\section{Footprinting Reactions}

The footprinting reactions were carried out with $20 \mu \mathrm{M}$ of a cationic hydroxysalicylidine-ethylenediamine-iron complex [iron 'salen'; Figure 2, c)], 2 mM DTT, the labelled DNA and an appropriate concentration of the ligand (absent in the control) in $10 \mathrm{~mm}$ tris $\cdot \mathrm{HCl}(\mathrm{pH}=7.4), 40 \mathrm{~mm} \mathrm{NaCl}$, and in a total reaction volume of $6 \mu \mathrm{L}$. The DNA/ligand complex was first incubated for $10 \mathrm{~min}$ at $37^{\circ} \mathrm{C}$. 'Salen' -mediated cleavage was initiated by rapidly mixing the above complex with solutions of 'salen' and DTT which were deposited on the walls of the Eppendorf tubes. The reactions were continued for $5 \mathrm{~min}$ at $37^{\circ} \mathrm{C}$ and subsequently quenched by quick chilling to $0{ }^{\circ} \mathrm{C}$ followed by the addition of formamide loading dye. These reaction mixtures were subsequently heated for $5 \mathrm{~min}$ at 95 ${ }^{\circ} \mathrm{C}$ and quickly chilled before loading into $8 \%$ polyacrylamide gel (containing $7 \mathrm{~m}$ urea). Gel electrophoresis was carried out at $1.75 \mathrm{kV}$. The gels were subsequently transferred into filter paper and autoradiographed at $-80^{\circ} \mathrm{C}$.

\section{Syntheses}

1-Methyl-4-nitro-1H-pyrrole-2-carboxylic Acid (5c): 1-Methyl- $1 \mathrm{H}$ pyrrole-2-carboxylic acid $(10 \mathrm{~g})$ was dissolved in $\mathrm{Ac}_{2} \mathrm{O}(60 \mathrm{~mL})$ at room temperature. This solution was cooled to $-25^{\circ} \mathrm{C}$. In a separate setup, $\mathrm{HNO}_{3}(70 \%, 8 \mathrm{~mL})$ was added dropwise to pre-cooled $\mathrm{Ac}_{2} \mathrm{O}(38 \mathrm{~mL})$ and the resulting solution was added dropwise to the above solution of 1-methyl-1 $H$-pyrrole-2-carboxylic acid over a period of $30 \mathrm{~min}$, keeping the temperature at $\approx-25^{\circ} \mathrm{C}$. The resulting solution was stirred at $-25^{\circ} \mathrm{C}$ for an additional $30 \mathrm{~min}$ and then allowed to come to room temperature. This was again cooled to $-25{ }^{\circ} \mathrm{C}$ to induce precipitation of the solid. This was filtered, washed with ice-cold $\mathrm{Ac}_{2} \mathrm{O}(5 \mathrm{~mL})$ and then with cold water, and 
finally dried in a dessicator over $\mathrm{P}_{2} \mathrm{O}_{5}(5.4 \mathrm{~g}, 40 \%)$. M.p. $204{ }^{\circ} \mathrm{C}$ (ref. ${ }^{[14 c]}$ m.p. $204-205^{\circ} \mathrm{C}$ ).

Methyl 1-Methyl-4-nitro-1 $\boldsymbol{H}$-pyrrole-2-carboxylate (5d): Compound 5c $(5.4 \mathrm{~g})$ was treated with a cold solution of conc. $\mathrm{H}_{2} \mathrm{SO}_{4}(5 \mathrm{~mL})$ in $\mathrm{MeOH}(100 \mathrm{~mL})$. The mixture was heated under reflux for $12 \mathrm{~h}$. $\mathrm{MeOH}$ was evaporated, water $(50 \mathrm{~mL})$ was added to the residue, and this was extracted with $\mathrm{CHCl}_{3}$. The organic layer was washed with brine, dried over anhydrous $\mathrm{Na}_{2} \mathrm{SO}_{4}$ and evaporated to obtain a solid $\left(5.6\right.$ g, 95\%); m.p. $113{ }^{\circ} \mathrm{C}$ (ref. ${ }^{[14 b]}$ m.p. $\left.114{ }^{\circ} \mathrm{C}\right)$. The ${ }^{1} \mathrm{H}$ NMR and IR of this compound matched with those reported in ref. ${ }^{[14 b]}$

Methyl 1-Methyl-4-\{[(1-methyl-1 $H$-pyrrol-2-yl)carbonyl]amino\}-1 $H$ pyrrole-2-carboxylate (6a): 1-Methyl- $1 H$-pyrrole-2-carboxylic acid (5a, $250 \mathrm{mg}, 2 \mathrm{mmol}$ ) was dissolved in $2 \mathrm{~mL}$ of dry THF and cooled in an ice bath. Freshly distilled $\mathrm{SOCl}_{2}(1 \mathrm{~mL})$ was added to the above solution with stirring. This solution was stirred at $0{ }^{\circ} \mathrm{C}$ for $1 \mathrm{~h}$ and then allowed to warm to room temp., and stirring was continued for $30 \mathrm{~min}$ at room temp. Excess $\mathrm{SOCl}_{2}$ was removed by evaporation under reduced pressure and the oil obtained (5b) was dissolved in $1 \mathrm{~mL}$ of THF.

In a separate setup, methyl 1-methyl-4-nitro-1 $H$-pyrrole-2-carboxylate (5d, $368 \mathrm{mg}, 2 \mathrm{mmol})$ was dissolved in DMF $(3 \mathrm{~mL})$ and hydrogenated over $\mathrm{Pd} / \mathrm{C}(5 \%, 460 \mathrm{mg})$ for $18 \mathrm{~h}$ at room temp. under slight positive pressure. The $\mathrm{Pd} / \mathrm{C}$ catalyst was filtered off, and the residue was washed twice with dry DMF (1 mL each). The combined filtrate and washings, along with $1 \mathrm{~mL}$ of triethylamine, were cooled to $-5^{\circ} \mathrm{C}$. The acid chloride $\mathbf{5 b}$, prepared as described above and dissolved in $\mathrm{CH}_{2} \mathrm{Cl}_{2}$, was added to this solution with stirring. Stirring was continued at $-5{ }^{\circ} \mathrm{C}$ for an additional hour and then at room temp. for $2 \mathrm{~h}$. At the end of this period, $\mathrm{CH}_{2} \mathrm{Cl}_{2}$ and excess triethylamine were removed by evaporation under vacuum. Ice-cold water was added to the resulting mixture with stirring. This furnished a white precipitate, which was extracted with EtOAc $(3 \times$ $15 \mathrm{~mL}$ ). The combined organic layers were washed successively with $5 \% \mathrm{NaHCO}_{3}$ solution, water, $1 \mathrm{~N} \mathrm{HCl}$ and brine, and were finally dried over $\mathrm{Na}_{2} \mathrm{SO}_{4}$. This was evaporated to obtain a solid (444 mg, 85\%). The solid obtained showed a single spot on TLC (silica gel, 20\% EtOAc/hexane, $R_{\mathrm{f}}=0.4$ ), m.p. $102{ }^{\circ} \mathrm{C}$. IR (nujol): $\tilde{v}=3300,1690,1620,1560,1530,1440,1400,1370,1300,1260$, $1240,1180,1100,1080,1060,1010,950,850,810,780,730,650$ $\mathrm{cm}^{-1} \cdot{ }^{1} \mathrm{H}$ NMR $\left(300 \mathrm{MHz}, \mathrm{CDCl}_{3}\right): \delta=3.81(\mathrm{~s}, 3 \mathrm{H}), 3.91(\mathrm{~s}, 3$ $\mathrm{H}), 3.97(\mathrm{~s}, 3 \mathrm{H}), 6.11\left(\mathrm{dd}, J_{1}=3.9 \mathrm{~Hz}, J_{2}=2.6 \mathrm{~Hz}, 1 \mathrm{H}\right), 6.62$ $\left(\mathrm{dd}, J_{1}=3.8 \mathrm{~Hz}, J_{2}=2.1 \mathrm{~Hz}, 1 \mathrm{H}\right), 6.74-6.77(\mathrm{~m}, 2 \mathrm{H}), 7.36(\mathrm{~d}$, $J=1.7 \mathrm{~Hz}, 1 \mathrm{H}), 7.5(\mathrm{~s}, 1 \mathrm{H}) \mathrm{ppm}$. LRMS (EI; m/z) calcd. for $\mathrm{C}_{13} \mathrm{H}_{15} \mathrm{~N}_{3} \mathrm{O}_{3}$ 261, found 261. $\mathrm{C}_{13} \mathrm{H}_{15} \mathrm{~N}_{3} \mathrm{O}_{3}$ : calcd. C 59.76, H 5.88, $\mathrm{N} 16.08$; found C 60.12, H 5.88, N 15.99 .

1-Methyl-4-\{[(1-methyl-1 $H$-pyrrol-2-yl)carbonyl]amino $\}$ - $1 H$-pyrrole2-carboxylic Acid (6c): The ester 6a (227 mg, $0.87 \mathrm{mmol})$ was dissolved in ethanol $(7 \mathrm{~mL})$. A solution of $\mathrm{NaOH}(173 \mathrm{mg})$ in water $(7 \mathrm{~mL})$ was added to the above solution and the mixture was heated under reflux for $1 \mathrm{~h}$. Ethanol was subsequently removed under reduced pressure and the remaining solution was washed with EtOAc $(2 \times 10 \mathrm{~mL})$, cooled and acidified with $0.5 \mathrm{~N} \mathrm{HCl}$. The solid that precipitated was extracted with EtOAc, dried over anhydrous $\mathrm{Na}_{2} \mathrm{SO}_{4}$ and evaporated to obtain an acid (6c), as a hygroscopic white solid (207 mg, $96 \%$ ), m.p. $175^{\circ} \mathrm{C}$. IR (nujol): $\tilde{v}=3440,3300$, $1660,1620,1580,1460,1420,1390,1320,1280,1250,1200,1160$, $1120,1100,1060,1020,930,820,810,780,720,690,650 \mathrm{~cm}^{-1} \cdot{ }^{1} \mathrm{H}$ NMR (300 MHz, [D 6 ]DMSO): $\delta=3.82(\mathrm{~s}, 3 \mathrm{H}), 3.86$ (s, $3 \mathrm{H}), 6.04$ $\left(\mathrm{dd}, J_{1}=3.8 \mathrm{~Hz}, J_{2}=2.6 \mathrm{~Hz}, 1 \mathrm{H}\right), 6.82(\mathrm{~d}, J=2.0 \mathrm{~Hz}, 1 \mathrm{H})$, 6.88 (br. s, $1 \mathrm{H}$ ), 6.94 (br. s, $1 \mathrm{H}), 7.41$ (d, $J=1.8 \mathrm{~Hz}, 1 \mathrm{H}), 9.81$ (s, $1 \mathrm{H})$ ppm. LR-MS (EI; $m / z, 30 \mathrm{eV}$ ) calcd. for $\mathrm{C}_{13} \mathrm{H}_{13} \mathrm{~N}_{3} \mathrm{O}_{3} 247$, found 247. $\mathrm{C}_{13} \mathrm{H}_{15} \mathrm{~N}_{3} \mathrm{O}_{3} \mathrm{H}_{2} \mathrm{O}$ : calcd. C 54.33, H 5.7, N 15.84; found C 54.43, H 5.77, N 15.6.

$\mathrm{N}, \mathrm{N}$-Dimethyl-3-\{[(1-methyl-4-\{[(1-methyl-1H-pyrrol-2-yl)carbonyl]amino\}-1 H-pyrrol-2-yl)carbonyl|amino\}propylamine (1) (D2): Compound 6c (189 mg, $0.76 \mathrm{mmol})$ was dissolved in DMF $(2 \mathrm{~mL})$ and cooled in an ice bath. $N$-hydroxysuccinimide (113 mg, 1.3 equiv.) was added to the above solution, followed by dicyclohexylcarbodiimide (205 mg, 1.3 equiv.). The solution was stirred for $1 \mathrm{~h}$ at $0{ }^{\circ} \mathrm{C}$, followed by stirring at room temp. for $6 \mathrm{~h}$. The DCU that precipitated was filtered off and the filtrate was diluted with EtOAc (30 $\mathrm{mL}$ ). The ethyl acetate layer was washed successively with $5 \%$ $\mathrm{NaHCO}_{3}$ and saturated brine and finally dried over anhydrous $\mathrm{Na}_{2} \mathrm{SO}_{4}$ to obtain the succinimide ester as a gummy solid. $N, N$ Dimethyl-1,3-diaminopropane $(1.2 \mathrm{mmol})$ was added to a solution of this ester in chloroform $(3 \mathrm{~mL})$, and the resulting solution was stirred at room temperature for $2 \mathrm{~h}$. At the end of this period, the reaction mixture was directly adsorbed on basic alumina and eluted with $4 \% \mathrm{CH}_{3} \mathrm{OH} / \mathrm{CHCl}_{3}$, followed by $10 \% \mathrm{CH}_{3} \mathrm{OH} / \mathrm{CHCl}_{3}$. The product was obtained as a gummy mass on evaporation of the solvent. Yield: $80 \%$. IR (thin film): $\tilde{v}=3300,1630,1580,1570,1560$, 1540, 1530, 1510, 1460, 1440, 1410, 1310, 1280, 1250, 1200, 1140, 1100, 1060, 1030, 1020, 900, 860, 810, 730, 690, $650 \mathrm{~cm}^{-1} \cdot{ }^{1} \mathrm{H}$ NMR $\left(300 \mathrm{MHz}, \mathrm{CDCl}_{3}\right): \delta=1.67-1.76(\mathrm{~m}, 2 \mathrm{H}), 2.23(\mathrm{~s}, 6 \mathrm{H})$, $2.40(\mathrm{t}, J=6.1 \mathrm{~Hz}, 2 \mathrm{H}), 3.40-3.46(\mathrm{~m}, 2 \mathrm{H}), 3.67(\mathrm{~s}, 3 \mathrm{H}), 3.73$ $(\mathrm{s}, 3 \mathrm{H}), 6.11\left(\mathrm{dd}, J_{1}=4.1 \mathrm{~Hz}, J_{2}=2.6,1 \mathrm{H}\right), 6.44(\mathrm{~d}, J=1.8 \mathrm{~Hz}$, $1 \mathrm{H}), 6.69\left(\mathrm{dd}, J_{1}=3.8 \mathrm{~Hz}, J_{2}=1.7 \mathrm{~Hz}, 1 \mathrm{H}\right), 6.75(\mathrm{t}, J=2.0 \mathrm{~Hz}$, $1 \mathrm{H}), 7.16(\mathrm{~d}, J=1.8 \mathrm{~Hz}, 1 \mathrm{H}), 7.55$ (br. s, $1 \mathrm{H}), 7.70(\mathrm{~s}, 1 \mathrm{H}) \mathrm{ppm}$. ${ }^{13} \mathrm{C}$ NMR $\left(100.6 \mathrm{MHz}, \mathrm{CDCl}_{3}\right): \delta=26.12\left(\mathrm{CH}_{2}\right), 36.55\left(\mathrm{NCH}_{3}\right.$, Ar) $36.70\left(\mathrm{NCH}_{3}, \mathrm{Ar}\right) 39.14\left(\mathrm{CH}_{2}\right), 45.38\left[\mathrm{~N}\left(\mathrm{CH}_{3}\right)_{2}\right], 58.73\left(\mathrm{CH}_{2}\right)$, 103.20 (CH, Ar), 107.36 (CH, Ar), $111.89(\mathrm{CH}, \mathrm{Ar}), 118.66(\mathrm{CH}$, Ar), 121.47 (C, Ar) 123.89 (C, Ar), 125.74 (C, Ar), $128.27(\mathrm{CH}$, Ar), $159.43(\mathrm{C}=\mathrm{O}), 161.80(\mathrm{C}=\mathrm{O}) \mathrm{ppm}$. LR-MS (EI; m/z, $30 \mathrm{eV})$ calcd. for $\mathrm{C}_{17} \mathrm{H}_{25} \mathrm{~N}_{5} \mathrm{O}_{2} 331$, found 331 .

Methyl 1-Methyl-4-\{[(1-methyl-4-nitro-1 $H$-pyrrol-2-yl)carbonyl]amino\}-1H-pyrrole-2-carboxylate (6b): 1-Methyl-4-nitro- $1 H$-pyrrole-2-carboxylic acid $(1.47 \mathrm{~g}, 8 \mathrm{mmol})$ was dissolved in dry DMF ( $5 \mathrm{~mL}$ ) and reduced over $\mathrm{H}_{2}-\mathrm{Pd} / \mathrm{C}(1.84 \mathrm{~g}, 5 \%)$ for $18 \mathrm{~h}$. Catalyst $\mathrm{Pd} / \mathrm{C}$ was filtered off and the residue was washed twice with dry DMF (2 $\mathrm{mL}$ each) and the combined filtrate and washings were cooled to $-5{ }^{\circ} \mathrm{C}$ in an ice-bath. Dry $\mathrm{Et}_{3} \mathrm{~N}(4.5 \mathrm{~mL})$ was added.

The acid chloride, 1-methyl-4-nitro- $1 \mathrm{H}$-pyrrole-2-carbonyl chloride, was prepared immediately before use. For this, $\mathrm{SOCl}_{2}(9 \mathrm{~mL})$ was added with cooling to a solution of 1-methyl-4-nitro- $1 \mathrm{H}$-pyrrole-2-carboxylic acid $(1.36 \mathrm{~g}, 8 \mathrm{mmol})$ in THF $(18 \mathrm{~mL})$, and the resulting solution was heated under reflux for $1 \mathrm{~h}$. THF and excess $\mathrm{SOCl}_{2}$ were removed by evaporation under vacuum and the residue was dissolved in $3 \mathrm{~mL}$ of $\mathrm{CH}_{2} \mathrm{Cl}_{2}$. This was added dropwise with stirring to a cooled solution of the amine derived from the reduction of $\mathbf{6 b}$. A yellow solid precipitated immediately, and stirring was continued for $1 \mathrm{~h}$ at $-5{ }^{\circ} \mathrm{C}$ and then at room temp. for another $1 \mathrm{~h}$. THF and excess $\mathrm{Et}_{3} \mathrm{~N}$ were removed under vacuum and $20 \mathrm{~mL}$ of ice-cold water was added to the above mixture with stirring. The precipitated solid was filtered and the precipitate was washed successively with water, $5 \% \mathrm{NaHCO}_{3}, 1 \mathrm{~N} \mathrm{HCl}$ and finally with methanol. The yellow solid obtained on drying weighed $2.15 \mathrm{~g}$ (87\%). M.p. $262^{\circ} \mathrm{C}$ (ref. ${ }^{[14 b]}$ m.p. $262{ }^{\circ} \mathrm{C}$ ). The ${ }^{1} \mathrm{H}$ NMR, IR and mass spectra were in agreement with the data reported in the literature. ${ }^{[14 b]}{ }^{13} \mathrm{C} \mathrm{NMR}\left(100.6 \mathrm{MHz},\left[\mathrm{D}_{6}\right] \mathrm{DMSO}\right): \delta=36.20\left(\mathrm{NCH}_{3}\right.$, Ar), $37.37\left(\mathrm{NCH}_{3}, \mathrm{Ar}\right), 50.97\left(\mathrm{OCH}_{3}\right), 107.62(\mathrm{CH}, \mathrm{Ar}), 108.41$ (CH, Ar) 118.94 (C, Ar), 120.86 (CH, Ar), 122.16 (C Ar), 126.16 
(C, Ar), $128.22(\mathrm{CH}, \mathrm{Ar}), 133.86(\mathrm{C}, \mathrm{Ar}), 156.97(\mathrm{C}=\mathrm{O}), 160.72$ $(\mathrm{C}=\mathrm{O}) \mathrm{ppm}$.

Methyl 1-Methyl-4-\{I(\{[(1-methyl-1 $H$-pyrrol-2-yl)carbonyl]amino\}1-methyl-1 $\boldsymbol{H}$-pyrrol-2-yl)carbonyl]amino $\mathbf{S}-\mathbf{H}$-pyrrole-2-carboxylate (7b): Compound $\mathbf{6 b}(1.38 \mathrm{~g}, 4.5 \mathrm{mmol})$ was dissolved in DMF (6 $\mathrm{mL}$ ) by warming and was subjected to hydrogenation over $\mathrm{Pd} / \mathrm{C}$ (1.04 g, 5\%). The obtained amine was immediately coupled with 1methyl- $1 H$-pyrrole-2-carboxylic acid through the intermediacy of the corresponding acid chloride by a procedure similar to that described for 6a. The solid obtained on workup was purified on a silica gel column with $\mathrm{CH}_{3} \mathrm{OH} / \mathrm{CHCl}_{3}$ (2:98) as eluent. Yield: $1.33 \mathrm{~g}$ (3.6 mmol, $80 \%$ ), m.p. $135{ }^{\circ} \mathrm{C}$. IR (nujol): $\tilde{v}=3300,1690,1680$, 1580, 1550, 1430, 1390, 1370, 1310, 1240, 1190, 1100, 1050, 820, 770, $720 \mathrm{~cm}^{-1} .{ }^{1} \mathrm{H}$ NMR $\left(300 \mathrm{MHz}, \mathrm{CDCl}_{3}\right): \delta=3.81(\mathrm{~s}, 3 \mathrm{H})$, $3.90(\mathrm{~s}, 3 \mathrm{H}), 3.93(\mathrm{~s}, 3 \mathrm{H}), 3.98(\mathrm{~s}, 3 \mathrm{H}), 6.13\left(\mathrm{dd}, J_{1}=4.1 \mathrm{~Hz}\right.$, $\left.J_{2}=2.6 \mathrm{~Hz}, 1 \mathrm{H}\right), 6.64\left(\mathrm{dd}, J_{1}=4.1 \mathrm{~Hz}, J_{2}=1.7 \mathrm{~Hz}, 1 \mathrm{H}\right), 6.70$ $(\mathrm{d}, J=1.8 \mathrm{~Hz}, 1 \mathrm{H}), 6.73(\mathrm{~d}, J=2.1 \mathrm{~Hz}, 1 \mathrm{H}), 6.77(\mathrm{t}, J=2.3 \mathrm{~Hz}$, $1 \mathrm{H}), 7.12(\mathrm{~d}, J=1.8 \mathrm{~Hz}, 1 \mathrm{H}), 7.41(\mathrm{~d}, J=2.1 \mathrm{~Hz}, 1 \mathrm{H}), 7.55$ (s, $1 \mathrm{H}), 7.58(\mathrm{~s}, 1 \mathrm{H}) \mathrm{ppm} .{ }^{13} \mathrm{C} \mathrm{NMR}\left(100.6 \mathrm{MHz}, \mathrm{CDCl}_{3}\right) 36.59$ $\left(\mathrm{NCH}_{3}, \mathrm{Ar}\right), 36.71\left(\mathrm{NCH}_{3}, \mathrm{Ar}\right), 36.76\left(\mathrm{NCH}_{3}, \mathrm{Ar}\right), 51.09\left(\mathrm{OCH}_{3}\right)$, 104.06 (CH, Ar), 107.50 (CH, Ar), $108.47(\mathrm{CH}, \mathrm{Ar}), 111.98(\mathrm{CH}$, Ar), 119.48 (CH, Ar), 119.95 (C, Ar), 121.07 (CH, Ar), 121.53 (C, Ar), 121.82 (C, Ar), 123.30 (C, Ar), 125.51 (C, Ar), 128.55 (C, Ar), $158.98(\mathrm{C}=\mathrm{O}), 159.58(\mathrm{C}=\mathrm{O}), 161.54(\mathrm{C}=\mathrm{O})$ ppm. LRMS (EI; $\mathrm{m} / z, 30 \mathrm{eV}$ ) calcd. for $\mathrm{C}_{19} \mathrm{H}_{21} \mathrm{~N}_{5} \mathrm{O}_{4} 383$, found 383. $\mathrm{C}_{19} \mathrm{H}_{21} \mathrm{~N}_{5} \mathrm{O}_{4} .0 .2$ $\mathrm{CHCl}_{3}$ : calcd. C 55.8, H 5.17, N 16.95; found C 56.03, H 5.36, N 17.3.

1-Methyl-4-\{I(\{I(1-methyl-1H-pyrrol-2-yl)carbonyl]amino\}-1-methyl1H-pyrrol-2-yl)carbonyl|amino\}-1 $\boldsymbol{H}$-pyrrole-2-carboxylic Acid (7c): The ester $(176 \mathrm{mg}, 0.46 \mathrm{mmol}$ ) was hydrolyzed by a procedure similar to that described for the hydrolysis of $\mathbf{6 c}$. The solid obtained on evaporation of ethyl acetate was purified on a silica gel column, with $4 \% \mathrm{CH}_{3} \mathrm{OH} / \mathrm{CHCl}_{3}$ followed by $8 \% \mathrm{CH}_{3} \mathrm{OH} / \mathrm{CHCl}_{3}$ as eluent. Evaporation of the solid gave an off-white solid (159 mg, 94\%), m.p. 102.7. IR (nujol): $\tilde{v}=3360,3110,1670,1630,1570,1550$, $1520,1500,1440,1400,1370,1300,1240,1200,1100,810,790,730$, $640 \mathrm{~cm}^{-1} .{ }^{1} \mathrm{H}$ NMR (300 MHz, [D $]$ DMSO): $\delta=3.89(\mathrm{~s}, 3 \mathrm{H})$, $3.93(\mathrm{~s}, 3 \mathrm{H}), 3.97(\mathrm{~s}, 3 \mathrm{H}), 6.08\left(\mathrm{dd}, J_{1}=3.4 \mathrm{~Hz}, J_{2}=2.6 \mathrm{~Hz}, 1\right.$ H), 6.76 (br. s, $1 \mathrm{H}), 6.91-6.93(\mathrm{~m}, 2 \mathrm{H}), 7.03(\mathrm{~d}, J=1.8 \mathrm{~Hz}, 1$ $\mathrm{H}), 7.27(\mathrm{~d}, J=1.8 \mathrm{~Hz}, 1 \mathrm{H}), 7.43(\mathrm{~d}, J=1.8 \mathrm{~Hz}, 1 \mathrm{H}), 7.65$ (br. s, $1 \mathrm{H}$ ), 9.50 (br. s, $2 \mathrm{H}$ ) ppm. LR-MS: (EI; $\mathrm{m} / \mathrm{z}, 30 \mathrm{eV}$ ) calcd. for $\mathrm{C}_{18} \mathrm{H}_{19} \mathrm{~N}_{5} \mathrm{O}_{4} 369$; found $325\left(\mathrm{M}-\mathrm{CO}_{2}\right)$. ESI-MS (+ve ion mode, $m / z)$ calcd. for $\mathrm{C}_{18} \mathrm{H}_{18} \mathrm{~N}_{5} \mathrm{O}_{4}\left(\mathrm{M}-\mathrm{H}^{+}\right)$368, found 368. $\mathrm{C}_{18} \mathrm{H}_{19} \mathrm{~N}_{5} \mathrm{O}_{4} .1 .05 \mathrm{H}_{2} \mathrm{O}$ : calcd. C 55.68, H 5.45, N 18.04; found $\mathrm{C}$ 55.4, H 5.27, N 18.39 .

$N, N$-Dimethyl-3-\{I(\{I(1-methyl-4-\{I(\{I(1-methyl-1 H-pyrrol-2-yl)carbonyl]amino\}-1-methyl-1 $\boldsymbol{H}$-pyrrol-2-yl)carbonyl]amino $\}-1 H$-pyrrol2-yl)carbonyl]amino\}propylamine (2) (D3): The acid 6c (159 mg, $0.5 \mathrm{mmol}$ ) was converted into the corresponding succinimide ester $\mathbf{7 d}$ by the same methodology as used for $\mathbf{6 d}$. This was purified on a silica gel column with $4 \% \mathrm{MeOH} / \mathrm{CHCl}_{3}$ as eluent to obtain the pure succinimide ester in $80 \%$ isolated yield, and this was used for the next step without further characterization. The activated ester $\mathbf{7 d}$ was then converted into $\mathbf{2}$ as described above for $\mathbf{1}$. The product was purified on an alumina column with $\mathrm{CH}_{3} \mathrm{OH} / \mathrm{CHCl}_{3}$ (10:90) as eluent. A sticky, hygroscopic solid was obtained on evaporation of the solvent (160 mg, 88\%). IR (nujol): $\tilde{v}=3260,1630,1570$, $1540,1530,1510,1460,1410,1400,1370,1310,1250,1200,1160$, $1110,1060,890,860,810,770,730,700 \mathrm{~cm}^{-1} .{ }^{1} \mathrm{H}$ NMR $(400 \mathrm{MHz}$, $\left.\mathrm{CDCl}_{3}\right): \delta=1.71-1.77(\mathrm{~m}, 2 \mathrm{H}), 2.30(\mathrm{~s}, 6 \mathrm{H}), 2.45(\mathrm{t}, J=6.1 \mathrm{~Hz}$, $2 \mathrm{H}), 3.44-3.48$ (m, $2 \mathrm{H}), 3.92(\mathrm{~s}, 3 \mathrm{H}), 3.94(\mathrm{~s}, 3 \mathrm{H}), 3.98(\mathrm{~s}, 3 \mathrm{H})$, $6.13\left(\mathrm{t}, J_{1}=2.7 \mathrm{~Hz}, 1 \mathrm{H}\right), 6.40(\mathrm{~d}, J=1.6 \mathrm{~Hz}, 1 \mathrm{H}), 6.67(\mathrm{~d}, J=$
$4.0 \mathrm{~Hz}, 1 \mathrm{H}), 6.73(\mathrm{~s}, 1 \mathrm{H}), 6.77(\mathrm{~s}, 1 \mathrm{H}), 7.08$ (s, $1 \mathrm{H}), 7.17$ (s, 1 $\mathrm{H}), 7.47$ (s, $1 \mathrm{H}), 7.58(\mathrm{~s}, 1 \mathrm{H}), 7.69$ (br. s, $1 \mathrm{H}) \mathrm{ppm} .{ }^{13} \mathrm{C} \mathrm{NMR}$ $\left(125 \mathrm{MHz}, \mathrm{CDCl}_{3}\right): \delta=26.12\left(\mathrm{CH}_{2}\right), 36.55\left(\mathrm{NCH}_{3}, \mathrm{Ar}\right) 36.83(2$ $\mathrm{NCH}_{3}$, Ar) $38.92\left(\mathrm{CH}_{2}\right), 45.29\left[\mathrm{~N}\left(\mathrm{CH}_{3}\right)_{2}\right], 58.36\left(\mathrm{CH}_{2}\right), 103.20$ $(\mathrm{CH}, \mathrm{Ar}), 103.91$ (CH, Ar), $107.40(\mathrm{CH}, \mathrm{Ar}), 112.26(\mathrm{CH}, \mathrm{Ar})$, 118.85 (CH, Ar), 119.29 (CH, Ar), 121.29 (C, Ar), 121.60 (C, Ar), 123.13 (C, Ar), 123.72 (C, Ar), 125.41 (C, Ar), 128.46 (CH, Ar), $159.09(\mathrm{C}=\mathrm{O}), 159.61(\mathrm{C}=\mathrm{O}), 161.92(\mathrm{C}=\mathrm{O}) \mathrm{ppm}$. ESI-MS $(\mathrm{m} / \mathrm{z})$ calcd. for $\mathrm{C}_{23} \mathrm{H}_{32} \mathrm{~N}_{7} \mathrm{O}_{3} \quad\left[\mathrm{MH}^{+}\right]$454.5, found 454.5. $\mathrm{C}_{23} \mathrm{H}_{31} \mathrm{~N}_{7} \mathrm{O}_{3} \cdot 2 \mathrm{H}_{2} \mathrm{O}$ : calcd. C 55.42, H 7.21, N 20.0; found C 56.06, H 6.89, N 19.6.

Methyl 1-Methyl-4-\{[(\{[(1-methyl-4-nitro-1 $H$-pyrrol-2-yl)carbonyl]amino -1-methyl-1 $\boldsymbol{H}$-pyrrol-2-yl)carbonyl]amino $\}$ - $\boldsymbol{H}$-pyrrole-2carboxylate (7a): Compound $\mathbf{6 b}(1.38 \mathrm{~g}, 4.5 \mathrm{mmol})$ was dissolved with warming in DMF $(6 \mathrm{~mL})$ and was reduced by hydrogenation over $5 \% \mathrm{Pd} / \mathrm{C}(1.04 \mathrm{~g})$ as described for $\mathbf{1 b}$. The reduced product was coupled with 1-methyl-4-nitropyrrole-2-carboxylic acid chloride by the procedure described for $\mathbf{6} \mathbf{b}$. Workup by the above procedure gave $1.61 \mathrm{~g}$ of a yellowish solid $\left(83 \%\right.$ ) m.p. $>270{ }^{\circ} \mathrm{C}$ (ref. ${ }^{[14 b]}>270$ $\left.{ }^{\circ} \mathrm{C}\right)$. This compound exhibited IR, ${ }^{1} \mathrm{H}$ NMR and mass spectra identical to those reported in the literature. ${ }^{[14 c]}{ }^{13} \mathrm{C}$ NMR (100.6 MHz, [D $]$ DMSO), $\delta=36.11\left(2 \mathrm{NCH}_{3}, \mathrm{Ar}\right), 37.42\left(\mathrm{NCH}_{3}\right.$, Ar), $50.88\left(\mathrm{NCH}_{3}, \mathrm{Ar}\right), 104.87(\mathrm{CH}, \mathrm{Ar}), 107.71\left(\mathrm{NCH}_{3}, \mathrm{Ar}\right)$, $108.60\left(\mathrm{NCH}_{3}, \mathrm{Ar}\right), 118.63(\mathrm{C}, \mathrm{Ar}), 118.83(\mathrm{CH}, \mathrm{Ar}), 120.83(\mathrm{CH}$, Ar), 121.56 (C, Ar), 122.96 (2 C, Ar), 126. 36 (C, Ar), $128.11(\mathrm{CH}$, Ar), $133.88(\mathrm{C}, \mathrm{Ar}), 157.01(\mathrm{C}=\mathrm{O}), 158.47(\mathrm{C}=\mathrm{O}), 160.83(\mathrm{C}=$ O) $\mathrm{ppm}$.

Methyl 1-Methyl-4-\{I(\{I(\{[(1-methyl-1H-pyrrol-2-yl)carbonyl]amino\}-1-methyl-1 $\boldsymbol{H}$-pyrrol-2-yl)carbonyl]amino\}-1 $\boldsymbol{H}$-pyrrol-2--yl)carbonyl]amino\}-1 $\boldsymbol{H}$-pyrrole-2-carboxylate $(\mathbf{8 b})$ : Compound 8 a (856 mg, $2 \mathrm{mmol}$ ) was dissolved in DMF (3 mL) and hydrogenated over Pd/C (460 mg, 5\%) as described for $6 \mathbf{b}$ and $7 \mathbf{a}$. The reduced material, after filtration, was coupled with 1-methyl-1 $H$-pyrrole-2carboxylic acid $(275 \mathrm{mg}, 2.2 \mathrm{mmol})$ through the intermediacy of the corresponding acid chloride, by the same procedure as described for $\mathbf{6 a}$ and $\mathbf{7 b}$. Evaporation of the organic layer after workup furnished a gummy solid, which was chromatographed on silica gel column with $\mathrm{MeOH} / \mathrm{CHCl}_{3}(4: 96)$ as eluent. The gummy solid obtained on evaporation of the solvent was dissolved in chloroform and precipitated with hexane. The solid obtained on evaporation of the solvents weighed $788 \mathrm{mg}(78 \%)$. M.p. $155.2{ }^{\circ} \mathrm{C} .{ }^{1} \mathrm{H}$ NMR (300 MHz, $\left.\mathrm{CDCl}_{3}\right): \delta=3.80(\mathrm{~s}, 3 \mathrm{H}), 3.86(\mathrm{~s}, 3 \mathrm{H}), 3.87$ (s, $3 \mathrm{H}), 4.02(\mathrm{~s}, 3 \mathrm{H}), 6.10\left(\mathrm{dd}, J_{1}=4.05 \mathrm{~Hz}, J_{2}=2.55 \mathrm{~Hz}, 1 \mathrm{H}\right)$, $6.60(\mathrm{~d}, J=2.1 \mathrm{~Hz}, 1 \mathrm{H}), 6.68(\mathrm{~d}, J=1.8 \mathrm{~Hz}, 1 \mathrm{H}), 6.69\left(\mathrm{dd}, J_{1}=\right.$ $\left.4.05 \mathrm{~Hz}, J_{2}=1.95 \mathrm{~Hz}, 1 \mathrm{H}\right), 6.76($ br. s, $1 \mathrm{H}), 6.81(\mathrm{~d}, J=1.8 \mathrm{~Hz}$, $1 \mathrm{H}), 7.08(\mathrm{~d}, J=1.8 \mathrm{~Hz}, 1 \mathrm{H}), 7.14$ (d, $J=1.8 \mathrm{~Hz}, 1 \mathrm{H}), 7.26$ (br. s, $1 \mathrm{H}), 7.42$ (d, $1.8 \mathrm{~Hz}, 1 \mathrm{H}), 7.59$ (s, $1 \mathrm{H}), 7.91$ (s, $1 \mathrm{H}), 8.05$ (s, 1 H) ppm. IR (nujol): $\tilde{v}=3280,1700,1630,1580,1550,1400,1380$, 1340, 1320, 1250, 1200, 1150, 1110, 1060, 800, 780, 730, $630 \mathrm{~cm}^{-1}$. LR-MS (EI; m/z) calcd. for $\mathrm{C}_{25} \mathrm{H}_{27} \mathrm{~N}_{7} \mathrm{O}_{5}$ 505.5, found 505 . $\mathrm{C}_{25} \mathrm{H}_{27} \mathrm{~N}_{7} \mathrm{O}_{5} .0 .3 \mathrm{CHCl}_{3}$ : calcd. C 56.13, H 5.08, N 18.11; found C 55.72, H 5.29, N 17.76 .

1-Methyl-4-\{I(\{I(\{I(1-methyl-1H-pyrrol-2-yl)carbonyl]amino $\}$-1methyl-1 $\boldsymbol{H}$-pyrrol-2-yl)carbonyl|amino $\}-1 \boldsymbol{H}$-pyrrol-2--yl)carbonyl]amino\}-1H-pyrrole-2-carboxylic Acid (8c): The ester $(252.5 \mathrm{mg}$, $0.5 \mathrm{mmol}$ ) was hydrolyzed by a procedure similar to that described for $\mathbf{7 b}$. After hydrolysis, the ethanol was evaporated under high vacuum and the resulting solution was washed with EtOAc, cooled to $20{ }^{\circ} \mathrm{C}$ and neutralized with $1 \mathrm{~N} \mathrm{HCl}$. The gel-like precipitate obtained was washed with water and dried in a dessicator over $\mathrm{P}_{2} \mathrm{O}_{5} \quad(225 \mathrm{mg}, 92 \%)$, m.p. $175.6{ }^{\circ} \mathrm{C} .{ }^{1} \mathrm{H} \quad \mathrm{NMR} \quad(300 \mathrm{MHz}$, [D $]$ DMSO): $\delta=3.88$ (s, $3 \mathrm{H}), 3.90$ (s, $3 \mathrm{H}), 3.92$ (s, $3 \mathrm{H}), 3.93$ (s, 
$3 \mathrm{H}), 3.96(\mathrm{~s}, 3 \mathrm{H}), 6.07\left(\mathrm{dd}, J_{1}=4.1 \mathrm{~Hz}, J_{2}=4.1 \mathrm{~Hz}, 1 \mathrm{H}\right) 6.78$ $(\mathrm{d}, J=2.1 \mathrm{~Hz}, 1 \mathrm{H}), 6.91\left(\mathrm{dd}, J_{1}=5.3 \mathrm{~Hz}, J_{2}=1.7 \mathrm{~Hz}, 1 \mathrm{H}\right)$, $7.08(\mathrm{~d}, J=1.8 \mathrm{~Hz}, 1 \mathrm{H}$ ), 7.09 (s, $J=1.8 \mathrm{~Hz}, 1 \mathrm{H}$ ), 7.25 (br. s, 1 H), $7.42(\mathrm{~d}, 1 \mathrm{H}), 9.64(\mathrm{~s}, 1 \mathrm{H}), 9.70(\mathrm{~s}, 1 \mathrm{H}), 9.72(\mathrm{~s}, 1 \mathrm{H}) \mathrm{ppm}$. IR (nujol): $\tilde{v}=3280,1630,1570,1530,1430,1400,1360,1300$, $1250,1200,1150,1100,1050,860,800,720 \mathrm{~cm}^{-1}$. MALDI-TOF $(\mathrm{m} / \mathrm{z})$ calcd. for $\mathrm{C}_{24} \mathrm{H}_{26} \mathrm{~N}_{7} \mathrm{O}_{5}\left[\mathrm{MH}^{+}\right]$491.6, found 491.7. $\mathrm{C}_{24} \mathrm{H}_{25} \mathrm{~N}_{7} \mathrm{O}_{5} .1 .25 \mathrm{NaCl}$ : calcd. C 51.05, $\mathrm{H}$ 4.46, N 17.37; found $\mathrm{C}$ 51.36, H 4.54, N 17.07.

$N, N$-Dimethyl-3-\{I(\{I(\{I(1-methyl-4-\{I(\{I(1-methyl-1 H-pyrrol-2yl)carbonyl]amino $\}$-1-methyl-1 $\boldsymbol{H}$-pyrrol-2-yl)carbonyl]amino $\}-1 H$ pyrrol-2-yl)carbonyl]amino $\boldsymbol{\}}$ - $\boldsymbol{H}$-pyrrol-2-yl)carbonyl]amino $\}$ propylamine (3) (D4): Compound 8c (123 mg, $0.25 \mathrm{mmol}$ ) was converted into the corresponding succinimide ester $8 \mathbf{d}$ by the same methodology as used for $\mathbf{6 d}$ and $\mathbf{7 d}$, and was purified by column chromatography as described for $\mathbf{7 d}$ ( $80 \%$ isolated yield). This was subsequently converted into $\mathbf{3}$ as described above for $\mathbf{1}$ and $\mathbf{2}$. The product was purified on an alumina column with $\mathrm{MeOH} / \mathrm{CHCl}_{3}$ (10:90) as eluent to obtain a gum, which was redissolved in $\mathrm{CHCl}_{3}$ and precipitated with petroleum ether. Solvent evaporation furnished a solid (104 mg, 90\%), m.p. 175.6. FT-IR (nujol): $\tilde{v}=3300$, $1630,1570,1520,1420,1390,1370,1330,1300,1240,1200,1100$, 1050, 800, 770, $720 \mathrm{~cm}^{-1} .{ }^{1} \mathrm{H}$ NMR $\left(300 \mathrm{MHz}, \mathrm{CDCl}_{3}\right): \delta=1.26$ (m, $2 \mathrm{H}$, merging with the water peak), $2.28(\mathrm{~s}, 6 \mathrm{H}), 2.43(\mathrm{t}, J=$ $6.3 \mathrm{~Hz}, 2 \mathrm{H}), 3.41-3.47$ (m, $2 \mathrm{H}), 3.89$ (s, $6 \mathrm{H}), 3.92(\mathrm{~s}, 3 \mathrm{H}), 3.98$ $(\mathrm{s}, 3 \mathrm{H}), 6.12\left(\mathrm{dd}, J_{2}=3.8 \mathrm{~Hz}, J_{1}=1.8 \mathrm{~Hz}, 1 \mathrm{H}\right), 6.52(\mathrm{~d}, J=$ $1.8 \mathrm{~Hz}, 1 \mathrm{H}), 6.65(\mathrm{~d}, J=1.8 \mathrm{~Hz}, 1 \mathrm{H}), 6.73\left(\mathrm{~d}, J_{1}=1.8 \mathrm{~Hz}, J_{2}=\right.$ $3.9 \mathrm{~Hz}, 1 \mathrm{H}), 7.75-6.77(\mathrm{~m}, 2 \mathrm{H}), 7.11$ (br. s, $2 \mathrm{H}), 7.2$ (d, $J=$ $1.8 \mathrm{~Hz}, 1 \mathrm{H}), 7.65(\mathrm{~s}, 1 \mathrm{H}), 7.71(\mathrm{~s}, 1 \mathrm{H}), 7.89$ (s, $1 \mathrm{H}), 7.91$ (s, 1 H) ppm. ${ }^{13} \mathrm{C}$ NMR $\left(75 \mathrm{MHz}, \mathrm{CDCl}_{3}\right): \delta=26.10\left(\mathrm{CH}_{2}\right), 36.47$ $\left(\mathrm{NCH}_{3}, \mathrm{Ar}\right), 36.60\left(\mathrm{NCH}_{3}, \mathrm{Ar}\right), 36.81\left(\mathrm{NCH}_{3}, \mathrm{Ar}\right), 38.54\left(\mathrm{CH}_{2}\right)$, $44.99\left[\mathrm{~N}\left(\mathrm{CH}_{3}\right)_{2}\right], 57.97\left(\mathrm{CH}_{2}\right), 103.42,103.96,104.19,107.38,112$, $6,118,95,119.54,119.69,121.38,121.61,121.66,122.81,123.04$, 123.40, 125.35, 128.49, $159.13(\mathrm{C}=\mathrm{O}), 159.20(\mathrm{C}=\mathrm{O}), 159.78(\mathrm{C}=$ O), $162.08(\mathrm{C}=\mathrm{O})$ ppm. ESI-MS $(\mathrm{m} / \mathrm{z})$ calcd. for $\mathrm{C}_{29} \mathrm{H}_{38} \mathrm{~N}_{9} \mathrm{O}_{4}$ $\left(\mathrm{MH}^{+}\right)$576.3, found 576.3. $\mathrm{C}_{29} \mathrm{H}_{37} \mathrm{~N}_{9} \mathrm{O}_{4} \cdot 0.45 \mathrm{CHCl}_{3}$ : calcd. $\mathrm{C}$ 56.07, H 6.0, N 20.03; found C 56.26, H 6.32, N 20.41.

Methyl 1-Methyl-4-\{I(\{I(\{I(1-methyl-4-nitro-1 H-pyrrol-2-yl)carbonyl]amino $\}$-1-methyl-1 $H$-pyrrol-2-yl)carbonyl]amino $\}-1 H$-pyrrole-2yl)carbonyl|amino\}-1 $\boldsymbol{H}$-pyrrole-2-carboxylate (8a): Compound $7 \mathbf{a}$ $(1 \mathrm{~g}, 2.34 \mathrm{mmol})$ was dissolved in DMF $(6 \mathrm{~mL})$, hydrogenated over $\mathrm{Pd} / \mathrm{C}(5 \%, 547 \mathrm{mg})$ as described for $\mathbf{6 b}$ and $7 \mathbf{a}$ and coupled with 1-methyl-4-nitro- $1 \mathrm{H}$-pyrrole-2-carboxylic acid (435 mg, $2.5 \mathrm{mmol}$ ) through the intermediacy of the corresponding acid chloride by the same procedure as used for $\mathbf{6 b}$ and $7 \mathbf{a}$. Yield: $840 \mathrm{mg}(1.46 \mathrm{mmol}$, $80 \%$ ), m.p. $282.2^{\circ} \mathrm{C}$. IR (nujol): $\tilde{v}=3400,1690,1630,1550,1420$, $1390,1320,1290,1240,1200,1140,1100,1050,870,800,770,740$ $\mathrm{cm}^{-1} .{ }^{1} \mathrm{H}$ NMR (400 MHz, [D $]$ DMSO): $\delta=3.74$ (s, $\left.3 \mathrm{H}\right), 3.84(\mathrm{~s}$, $3 \mathrm{H}), 3.85$ (s, $3 \mathrm{H}), 3.85$ (s, $3 \mathrm{H}), 3.87$ (s, $3 \mathrm{H}), 3.97$ (s, $3 \mathrm{H}), 6.91$ $(\mathrm{s}, 1 \mathrm{H}), 7.06(\mathrm{~s}, 1 \mathrm{H}), 7.08(\mathrm{~s}, 1 \mathrm{H}), 7.26(\mathrm{~s}, 1 \mathrm{H}), 7.29(\mathrm{~s}, 1 \mathrm{H})$, 7.47 (s, $1 \mathrm{H}), 7.60$ (s, $1 \mathrm{H}), 8.18$ (s, $1 \mathrm{H}), 9.96$ (s, $1 \mathrm{H}), 10.01$ (s, 1 $\mathrm{H}), 10.31(\mathrm{~s}, 1 \mathrm{H}) \mathrm{ppm} .{ }^{13} \mathrm{C} \mathrm{NMR}\left(400 \mathrm{MHz},\left[\mathrm{D}_{6}\right] \mathrm{DMSO}\right): \delta=$ $36.12\left(3 \mathrm{NCH}_{3}, \mathrm{Ar}\right), 37.41\left(\mathrm{NCH}_{3}, \mathrm{Ar}\right), 50.89\left(\mathrm{OCH}_{3}\right), 104.67(\mathrm{CH}$, $\mathrm{Ar}), 104.93(\mathrm{CH}, \mathrm{Ar}), 107.58(\mathrm{CH}, \mathrm{Ar}), 108.52(\mathrm{CH}, \mathrm{Ar}), 118.69$ (2CH, Ar), 120.78 (CH, Ar), 121.44 (C, Ar), 122.23 (C, Ar), 122.64 (C, Ar), 123.0 (3 C, Ar), 126.36 (C, Ar), 128.13 (CH, Ar), 133.87 $(\mathrm{C}, \operatorname{Ar}), 156.99(\mathrm{C}=\mathrm{O}), 158.46(2 \mathrm{C}=\mathrm{O}), 160.82(\mathrm{C}=\mathrm{O}) \mathrm{ppm}$. MALDI-TOF $(\mathrm{m} / \mathrm{z})$ calcd. for $\mathrm{C}_{25} \mathrm{H}_{27} \mathrm{~N}_{8} \mathrm{O}_{7}\left[\mathrm{MH}^{+}\right]$551.2, found 551.2 .

Methyl 1-Methyl-4-\{I(\{I(\{I(\{I(1-methyl-1 $H$-pyrrol-2-yl)carbonyl]amino -1-methyl-1 $\boldsymbol{H}$-pyrrol-2-yl)carbonyl]amino $\}$ - $1 H$-pyrrol-2-yl)carbonyl]amino $\}$ - $1 H$-pyrrole-2-yl)carbonyl]amino $\}-1 H$-pyrrole-2-carb- oxylate (9a): Compound 8a (675 mg, $1.23 \mathrm{mmol}$ ) was dissolved in DMF $(6 \mathrm{~mL})$, reduced by hydrogenation over Pd/C $(5 \%, 282 \mathrm{mg})$ as described for $\mathbf{7 a}$ and $\mathbf{8 a}$, and coupled with 1-methyl-1 $H$-pyrrole2-carboxylic acid (184 mg, $1.48 \mathrm{mmol}$ ) through the intermediacy of the corresponding acid chloride by the same procedure as used for the synthesis of $\mathbf{6 a}, \mathbf{7} \mathbf{b}$ and $\mathbf{8 b}$. The product obtained was purified by chromatography on a silica gel column with a $8: 92 \mathrm{CH}_{3} \mathrm{OH} /$ $\mathrm{CHCl}_{3}$ solvent mixture as eluent. Yield $576 \mathrm{mg}(85 \%)$. M.p. 221.2 ${ }^{\circ} \mathrm{C}$. IR (nujol): $\tilde{v}=3300,1710,1650,1590,1550,1440,1410,1390$, 1320, 1260, 1210, 1160, 1120, 1070, 890, 810, 790, $750 \mathrm{~cm}^{-1} \cdot{ }^{1} \mathrm{H}$ NMR $\left(300 \mathrm{MHz}, \mathrm{CDCI}_{3}\right): \delta=3.80(\mathrm{~s}, 3 \mathrm{H}), 3.74(\mathrm{~s}, 3 \mathrm{H}), 3.77(\mathrm{~s}$, $3 \mathrm{H}$ ), 3.79 (s, $6 \mathrm{H}), 3.89$ (s, $3 \mathrm{H}), 6.03$ (br. s, $1 \mathrm{H}$ ), 6.58 (br. s, $2 \mathrm{H}$ ), 6.70 (br. s, $3 \mathrm{H}$ ), 6.80 (br. s, $1 \mathrm{H}$ ), 7.00 (br. s, $1 \mathrm{H}$ ), 7.04 (br. s, 1 H), 7.13 (br. s, $1 \mathrm{H}$ ), 7.37 (br. s, $1 \mathrm{H}$ ), 7.97 (br. s, $2 \mathrm{H}$ ), 8.19 (br. s, $1 \mathrm{H}), 8.39$ (br. s, $1 \mathrm{H}$ ) ppm. ESI-MS $(\mathrm{m} / \mathrm{z})$ calcd. for $\mathrm{C}_{31} \mathrm{H}_{34} \mathrm{~N}_{9} \mathrm{O}_{6}$ $\left[\mathrm{MH}^{+}\right]$628.3, found 628.3. $\mathrm{C}_{31} \mathrm{H}_{33} \mathrm{~N}_{9} \mathrm{O}_{6} \cdot 0.7 \mathrm{CHCl}_{3}$ : calcd. C 53.53, $\mathrm{H}$ 4.78, N 17.72; found C 53.55, H 5.1, N 17.76.

1-Methyl-4-\{I(\{I(\{I(\{I(1-methyl-1 H-pyrrol-2-yl)carbonyl]amino\}-1methyl-1 $H$-pyrrol-2-yl)carbonyl]amino $\}-1 H$-pyrrol-2--yl)carbonyl]amino\}-1 $H$-pyrrole-2--yl)carbonyl]amino\}-1 $H$-pyrrole-2-carboxylic Acid (9b): The ester 9a (348 mg, $0.55 \mathrm{mmol}$ ) was dissolved in ethanol $(5 \mathrm{~mL})$. A solution of $\mathrm{NaOH}(207 \mathrm{mg})$ in water $(5 \mathrm{~mL})$ was added to the above solution and the mixture was heated under reflux for $30 \mathrm{~min}$. Ethanol was then removed under reduced pressure and the remaining material was washed with EtOAc $(2 \times 10$ $\mathrm{mL}$ ), cooled and acidified with $0.5 \mathrm{~N} \mathrm{HCl}$. This afforded a gel-like precipitate, which was filtered, washed with water and dried in a dessicator over $\mathrm{P}_{2} \mathrm{O}_{5}$. Yield: $322 \mathrm{mg}(90 \%)$; m.p. $288.7^{\circ} \mathrm{C}$. IR (nujol): $\tilde{v}=3280,1630,1570,1540,1420,1390,1360,1330,1310$, 1240, 1290, 1140, 1100, 1050, 990, 880, 760, $720 \mathrm{~cm}^{-1} .{ }^{1} \mathrm{H}$ NMR (300 MHz, [D 6 DMSO): $\delta=4.02$ (s, $3 \mathrm{H}), 4.07$ (br. s, $9 \mathrm{H}$ ), 4.11 (s, $3 \mathrm{H}), 6.21$ (br. s, $1 \mathrm{H}$ ), 6.90 (br. s, $1 \mathrm{H}$ ), 7.05 (br. s, $2 \mathrm{H}$ ), 7.14 (br. s, $3 \mathrm{H}$ ), 7.44 (br. s, $3 \mathrm{H}$ ), 7.57 (s, $1 \mathrm{H}$ ), 9.70 (br. s, $5 \mathrm{H}$ ) ppm. MALDI-TOF $(\mathrm{m} / \mathrm{z})$ calcd. for $\mathrm{C}_{30} \mathrm{H}_{31} \mathrm{~N}_{9} \mathrm{O}_{6} \mathrm{Na}[\mathrm{M}+\mathrm{Na}]^{+}$636.6, found 636.6. $\mathrm{C}_{30} \mathrm{H}_{31} \mathrm{~N}_{9} \mathrm{O}_{6} \cdot \mathrm{H}_{2} \mathrm{O}$ : calcd. C 57.04, H 5.27, N 19.96; found C 57.36, H 5.36, N 19.61.

$N, N$-Dimethyl-3-\{I(\{I(\{IC\{I(1-methyl-4-\{I(\{I(1-methyl-1H-pyrrol-2yl)carbonyl]amino $\}$-1-methyl-1 $H$-pyrrol-2-yl)carbonyl]amino $\}-1 H$ pyrrol-2-yl)carbonyl]amino\}-1 $\boldsymbol{H}$-pyrrol-2-yl)carbonyl]amino $\}-1 H$ pyrrol-2-yl)carbonyl|amino\}propylamine (4) (D5): The acid 9b $(230 \mathrm{mg}, 0.33 \mathrm{mmol})$ was converted into the succinimide ester $\mathbf{9 c}$ as described above for $\mathbf{6 d}, \mathbf{7 d}$ and $\mathbf{8 d}$. This was then purified by column chromatography as described above for 7d and 8d. Aminolysis of the ester with $N, N$-dimethyl-1,3-diaminopropane and subsequent purification of the crude product on neutral alumina column with $\mathrm{MeOH} / \mathrm{CHCl}_{3}(12: 88)$ yielded 4 as an off-white solid (151 mg, 82\%), m.p. $238.8^{\circ} \mathrm{C}$. FT-IR (thin film): $\tilde{v}=3303,2941$, 1639, 1582, 1543, 1465, 1434, 1404, 1346, 1317, 1255, 1207, 1161, 1111, 1061, 1018, 887, 810, 773, $737 \mathrm{~cm}^{-1} .{ }^{1} \mathrm{H}$ NMR $(300 \mathrm{MHz}$, $\left.\mathrm{CDCl}_{3}\right): \delta=1.61-65(\mathrm{~m}, 2 \mathrm{H}), 2.15(\mathrm{~s}, 6 \mathrm{H}$, merging with the water peak), $2.31(\mathrm{t}, J=3.8 \mathrm{~Hz}, 2 \mathrm{H}), 3.31-3.33(\mathrm{~m}, 2 \mathrm{H}), 3.72(\mathrm{~s}$, $6 \mathrm{H}), 3.76(\mathrm{~s}, 3 \mathrm{H}), 3.78(\mathrm{~s}, 3 \mathrm{H}), 3.89(\mathrm{~s}, 3 \mathrm{H}), 6.02(\mathrm{t}, J=3.0 \mathrm{~Hz}$, $1 \mathrm{H}), 6.52(\mathrm{~s}, 1 \mathrm{H}), 6.56(\mathrm{~s}, 1 \mathrm{H}), 6.60(\mathrm{~s}, 1 \mathrm{H}), 6.68$ (br. s, $2 \mathrm{H})$, 6.72 (br. s, $1 \mathrm{H}), 6.99$ (s, $1 \mathrm{H}), 7.08$ (s, $1 \mathrm{H}), 7.11$ (s, $1 \mathrm{H}), 7.14$ (s, $1 \mathrm{H}), 7.57$ (br. s, $1 \mathrm{H}), 8.04$ (s, $1 \mathrm{H}), 8.15$ (s, $1 \mathrm{H}), 8.47$ (br. s, $2 \mathrm{H}$ ) ppm. ${ }^{13} \mathrm{C}$ NMR (100.6 MHz, [D $]$ DMSO): $\delta=26.16\left(\mathrm{CH}_{2}\right), 36.50$ $\left(4 \mathrm{NCH}_{3}, \mathrm{Ar}\right), 36.78\left(\mathrm{NCH}_{3}, \mathrm{Ar}\right), 45.10\left(\mathrm{~N}\left(\mathrm{CH}_{3}\right)_{2}\right], 58.32\left(\mathrm{CH}_{2}\right)$, 103.49, 103.97, 104.39 (2C), 107.47, 112.60, 119.04, 119.60, 119.98, 121.53 (2C), 121.81 (2C), 122.95, 123.27, 123.63, 125.47, 128.53, $159.23(2 \mathrm{C}=\mathrm{O}), 159.47(\mathrm{C}=\mathrm{O}), 159.85(\mathrm{C}=\mathrm{O}), 162.16(\mathrm{C}=\mathrm{O}) \mathrm{ppm}$. ESI-MS $(\mathrm{m} / \mathrm{z})$ calcd. for $\mathrm{C}_{35} \mathrm{H}_{44} \mathrm{~N}_{11} \mathrm{O}_{5}\left[\mathrm{MH}^{+}\right]$698.4, found 698.4. $\mathrm{C}_{35} \mathrm{H}_{44} \mathrm{~N}_{11} \mathrm{O}_{5}$ 0.75CHCl 3 : calcd. C 54.46, H 5.6, N 19.54; found $\mathrm{C}$ 54.78, H 6.03, N 19.77 . 
[1] [1a] P. B. Dervan, R. W. Burli, Curr. Opin. Chem. Biol. 1999, 3, 688-693. ${ }^{[1 \mathrm{~b}]}$ C. Bailly, J. B. Chaires, Bioconjugate Chem. 1998 , 9, 513-538. ${ }^{[1 \mathrm{c}]}$ A. L. Satz, T. C. Bruice, J. Am. Chem. Soc. 2001, 123, 2469-2477. ${ }^{[1 \mathrm{~d}]}$ F. A. Tanious, W. D. Wilson, D. A. Patrick, R. R. Tidwell, P. Colson, C. Houssier, C. Tardy, C. Bailly, Eur. J. Biochem. 2001, 268, 3455-3464. [1e] S. K. Sharma, M. Tandon, J. W. Lown, J. Org. Chem. 2000, 65, $1102-1107 .{ }^{[1 f]}$ B. Toshikazu, H. Iida, I. Saito, H. Sugiyama, J. Am. Chem. Soc. 2001, 123, 5158-5159. ${ }^{[1 \mathrm{~g}]}$ M. Pitie, J. D. Van Horn, D. Brion, C. J. Burrows, B. Meunier, Bioconjugate Chem. 2000, 11, 892-900. ${ }^{[1 \mathrm{~h}]}$ P. Helissey, S. G. Renault, P. Colson, C. Houssier, C. Bailly, Bioconjugate Chem. 2000, 11, 219-227.

[2] S.-Y. Chiang, J. Welch, F. J. Rauscher III, T. A. Teerman, Biochemistry 1994, 33, 7033- 7040.

[3] [3a] D. J. Patel, Proc. Natl. Acad. Sci. USA 1982, 79, 6424-6428. ${ }^{[3 \mathrm{~b}]}$ M. L. Kopka, C. Yoon, D. Goodsell, P. Pjura, R. E. Dickerson, Proc. Natl. Acad. Sci. USA 1985, 82, 1376-1380. ${ }^{[3 c]}$ X. Chen, B. Ramakrishnan, S. T. Rao, M. Sundarlingam, Nat. Struct. Biol. 1994, 1, 169-174. ${ }^{[3 \mathrm{~d}]}$ B. H. Geierstanger, M. Mrksich, P. B. Dervan, D. E. Wemmer, Science 1994, 266, 646-650.

${ }^{[4]}{ }^{[4 a]}$ K. J. Breslauer, D. P. Remeta, W.-Y. Chou, R. Ferrante, J. Curry, D. Zaunczkowski, J. G. Snyder, L. A. Marky, Proc. Natl. Acad. Sci. USA 1987, 84, 8922-8926. ${ }^{[4 b]}$ D. Rentzeperis, L. Marky, T. J. Dwyer, B. H. Geierstanger, J. G. Pelton, D. E. Wemmer, Biochemistry 1995, 34, 2937-2945. ${ }^{[4 c]}$ D. J. Patel, H. Berglund, L. Nilsson, R. Rigler, L. W. McLaughlin, A. Graslund, Eur. J. Biochem. 1992, 203, 361-366. ${ }^{[4 d]}$ M. Suzann, F. A. Tanious, D. Ding, A. Kumar, D. W. Boykin, I. L. Simpson, S. Neidle, W. D. Wilson, J. Mol. Biol. 2000, 300, 321-337.

[5] [5a] G. Luck, C. Zimmer, K.-E. Reinert, F. Arcamone, Nucleic Acids Res. 1977, 4, 2655-2670. [5b] C. Zimmer, G. Luck, H. Thrum, C. Pitra, Eur. J. Biochem. 1972, 26, 81-89. ${ }^{[5 c]}$ P. Parrack, D. Dasgupta, J. Ayyer, V. Sasisekaran, FEBS Lett. 1987, 212, 297-301. ${ }^{[5 d]}$ A. S. Krylov, S. L. Grokhovsky, A. S. Zasedatelev, A. L. Zhuze, G. V. Gursky, B. P. Gottikh, Nucleic. Acids. Res. 1979, 6, 289-304. [5e] G. Adlam, I. S. Blagbrough, S. Taylor, H. C. Latham, I. S. Haworth, A. Rodger, Bio Org. Med. Chem. Lett. 1994, 4, 2435-2440.

${ }^{[6]}$ C. L. Kielkopf, S. White, J. W. Szewczyk, J. M. Turner, E. E. Baird, D. C. Rees, Science 1998, 282, 111-115.

[7] L. Gottesfield, L. Neely, J. W. Trauger, E. E. Baird, P. B. Dervan, Nature 1997, 387, 202-205.

${ }^{[8]}\left[{ }^{8 a}\right]$ W. H. Gmeiner, W. Cui, D. E. Konerding, P. A. Keifer, S. K. Sharma, A. M. Soto, L. A. Marky, J. W. Lown, J. Biomol. Struct. Dyn. 1999, 17, 507-518. [8b] A. Randazzo, A. Galeone and L. Mayol, Chem. Commun. 2001, 1030-1031. [8c] J. R. Williamson, Annu. Rev. Biophys. Biomol. Struct. 1994, 23, 703-730. ${ }^{[8 d]}$ D. Sun, B. Thompson, B. E. Cathers, M. Salazer, S. M. Kerwin, J. O. Trent, T. C. Jenkins, S. Neidle, L. H. Hurley, J. Med. Chem. 1997, 40, 2113-2116. ${ }^{[8 \mathrm{e}]}$ R. T. Wheelhouse,
D. Sun, H. Han, F. X. Han, L. H. Hurley, J. Am. Chem. Soc. 1998, 120, 3261-3262.

[9] S. Das, G. S. Kumar, M. Maiti, Biophys. Chem. 1999, 76, 199-218.

[10] [10a] C. Zimmer, N. Kakiuchi, W. Guschlbauer, Nucleic. Acids. Res. 1982, 10, 1721-1732. ${ }^{[10 b]}$ Ch. Zimmer, C. Marck, W. Guschlbauer, FEBS Lett. 1983, 154, 156-160. ${ }^{[10 c]}$ G. Burckhardt, A. Walter, C. Zimmer, J. Biomol. Struct. Dyn. 1996, 13, 671-676. ${ }^{[10 \mathrm{~d}]}$ C. Marck, N. Kakiuchi, W. Guschlbauer, Nucleic Acids. Res. 1982, 10, 6147-61.

[11] K. E. Rao, N. Ramesh, D. Choudhury, S. K. Brahmachary, V. Sasisekaran, J. Biomol. Struct. Dyn. 1989, 7, 335-345.

[12] [12a] W. Zacharias, A. Jaworski, J. E. Larson, R. D. Wells, Proc. Natl. Acad. Sci. USA 1988, 85, 7069-7063. [12b] A. Nordheim, M. L. Pardue, E. M. Lafer, A. Moller, B. D. Stollar, A. Rich, Nature 1981, 294, 417-420. ${ }^{[12 \mathrm{c}]}$ B. Wittig, T. Dorbic, A. Rich, Proc. Natl. Acad. Sci. USA 1991, 88, 2259-2263. [12d] A. Nordheim, A. Rich, Proc. Natl. Acad. Sci. USA 1983, 80 1821-1825. ${ }^{[12 \mathrm{e}]}$ A. Jimenez-Ruiz, J. M. Requena, M. C. Lopez, C. Alonso, Proc. Natl. Acad. Sci. USA 1991, 88, 31-35.

[13] [13a] E. E. Baird, P. B. Dervan, J. Am. Chem. Soc. 1996, 118, 6141-6146. [13b] P. B. Dervan, Organic Letters 2001, 3, $1201-1203$

[14] [14a] F. Frcamone, S. Penco, P. Orezzi, V. Nicolella, A. Pirelli, Nature 1964, 203, 1064-1065. ${ }^{[14 b]}$ M. Bialer, B. Yagen, R. Mecholum, Tetrahedron 1978, 34, 2389-2391. [14c] J. W. Lown, K. Krowicki, J. Org. Chem. 1985, 50, 3774-3779. [14d] L. Grehn, U. Ragnarsson, J. Org. Chem. 1981, 46, 3492-3497. ${ }^{[14 \mathrm{e}]}$ K. E. Rao, Y. Bathni, J. W. Lown, J. Org. Chem. 1990, 55, 728-737. ${ }^{[14 f]}$ L. Ding, L. Grehn, E. De Clercq, G. Andrei, R. Snoeck, J. Balzarini, B. Fransson, U. Ragnarson, Acta Chemica Scand. 1994, 48, 498-505. ${ }^{[14 \mathrm{~g}]}$ W. S. Wade, M. Mrksich, P. B. Dervan, J. Am. Chem. Soc. 1992, 114, 8783-8794. ${ }^{[14 \mathrm{~h}]}$ G.-X. He, K. A. Browne, J. C. Croppe, A. Blasko, H.-Y. Mei, T. C. Bruice, J. Am. Chem. Soc. 1993, 115, 7061-7071.S. ${ }^{[14 i]}$ Bhattacharya, M. Thomas, Tetrahedron Lett. 2000, 41, 5571-75.

${ }^{[15]}$ M. P. Singh, S. Kumar, T. Joseph, R. T. Pon, J. W. Lown, Biochemistry 1992, 31, 6453-6461.

${ }^{[16] ~[16 a] ~ M . ~ L e e, ~ A . ~ L . ~ R h o d e s, ~ M . ~ D . ~ W y a t t, ~ S . ~ F o r r o w, ~ J . ~ A . ~ H a r t-~}$ ley, Biochemistry 1993, 32, 4237-4245. ${ }^{[16 b]}$ A. J. Geall, D. AlHadithi, I. S. Balbrough, Bioconjugate Chem. 2002, 13, 481-490 and the references given therein.

${ }^{[17] ~[17 a] ~ I . ~ S . ~ B l a g b r o u g h, ~ S . ~ T a y l o r, ~ M . ~ L . ~ C a r p e n t e r, ~ V . ~ N o v o s e l-~}$ skiy, T. Shamma, I. S. Haworth, Chem. Commun. 1998, 929-930. ${ }^{[17 b]}$ S. S. Mandal, U. Varshney, S. Bhattacharya, Bioconjugate Chem. 1997, 8, 798-812. ${ }^{[17 \mathrm{c}]}$ S. S. Mandal, 1998, $\mathrm{PhD}$ Thesis, Department of Organic Chemistry, Indian Institute of Science, Bangalore, India.

${ }^{[18]}$ A. Rodger, I. S. Balabrough, G. Adlam, M. L. Carpenter, Biopolymers 1994, 34, 1583-1593.

${ }^{[19]}$ X. Chen, B. Ramakrishnan, M. Sundarlingam, Nat. Struct. Biol. 1995, 2, 733-735.

${ }^{[20]}$ J. J. Kelly, E. E. Baird, P. B. Dervan, Proc. Natl. Acad. Sci. USA 1996, 93, 6981-6985. 